bioRxiv preprint doi: https://doi.org/10.1101/2021.02.10.430272; this version posted February 10, 2021. The copyright holder for this preprint (which was not certified by peer review) is the author/funder, who has granted bioRxiv a license to display the preprint in perpetuity. It is made available under aCC-BY-NC-ND 4.0 International license.

Godet, David, Roussel et al, February 2021

\title{
Long non-coding RNA Neat1 is a key translational regulator in hypoxia.
}

Anne-Claire Godet ${ }^{1 *}$, Florian David ${ }^{1 *}$, Emilie Roussel ${ }^{1 *}$, Fransky Hantelys ${ }^{1}$, Florent Morfoisse $^{1}$, Joffrey Alves ${ }^{1}$, Françoise Pujol ${ }^{1}$, Isabelle Ader ${ }^{2}$, Edouard Bertrand ${ }^{3}$, Odile BurletSchiltz ${ }^{4}$, Carine Froment ${ }^{4}$, Anthony K. Henras ${ }^{5}$, Patrice Vitali ${ }^{5}$, Eric Lacazette ${ }^{1}$, Florence Tatin $^{1}$, Barbara Garmy-Susini ${ }^{1}$, and Anne-Catherine Prats ${ }^{1 \S}$

${ }^{1}$ UMR 1297-I2MC, Inserm, Université de Toulouse, UT3, Toulouse, France.

${ }^{2}$ UMR 1031-STROMALAB, Inserm, CNRS ERL5311, Etablissement Français du SangOccitanie (EFS), National Veterinary School of Toulouse (ENVT), Université de Toulouse, UT3, Toulouse, France.

${ }^{3}$ UMR5535 CNRS-IGMM, Université de Montpellier, Montpellier, France

${ }^{4}$ Institut de Pharmacologie et Biologie Structurale (IPBS), Université de Toulouse, CNRS, UT3, Toulouse, France

${ }^{5}$ UMR 5099-LBME, CBI, CNRS, Université de Toulouse, UT3, Toulouse, France

* Equal contribution

$\S$ Corresponding author.

Contact information: Anne-Catherine Prats, Institut des Maladies Métaboliques et Cardiovasculaires, 1, Avenue Jean Poulhes, BP 84225, 31432 Toulouse cedex 4, France (email: Anne-Catherine.Prats@inserm.fr)

Running title: Translational control by lncRNA Neat1 in hypoxia

\section{Highlights}

- Induction of lncRNA Neat1 and paraspeckle formation correlates with activation of IRES-dependent translation in hypoxic cardiomyocytes.

- Neat1, an essential paraspeckle component, is the key IRES trans-acting factor (ITAF) of (lymph)angiogenic and cardioprotective factor mRNA IRESs.

- Paraspeckle proteins $\mathrm{p} 54^{\mathrm{nrb}}$ and PSPC1 as well as nucleolin and Rps2, two p54 $4^{\text {nrb }}$ interacting proteins, are ITAFs of IRES subgroups.

- Paraspeckle appears as a platform for IRESome formation in nucleus.

- The Neat1_2 isoform plays a pivotal role in translation of mRNA containing IRESs and of genes involved in the stress response. 
bioRxiv preprint doi: https://doi org/10.1101/2021.02 10.430272· this version posted February 10, 2021. The copyright holder for this preprint (which was not certified by peer review) is the author/funder, who has granted bioRxiv a license to display the preprint in perpetuity. It is made available under aCC-BY-NC-ND 4.0 International license.

Godet, David, Roussel et al, February 2021

\section{GRAPHICAL ABSTRACT}

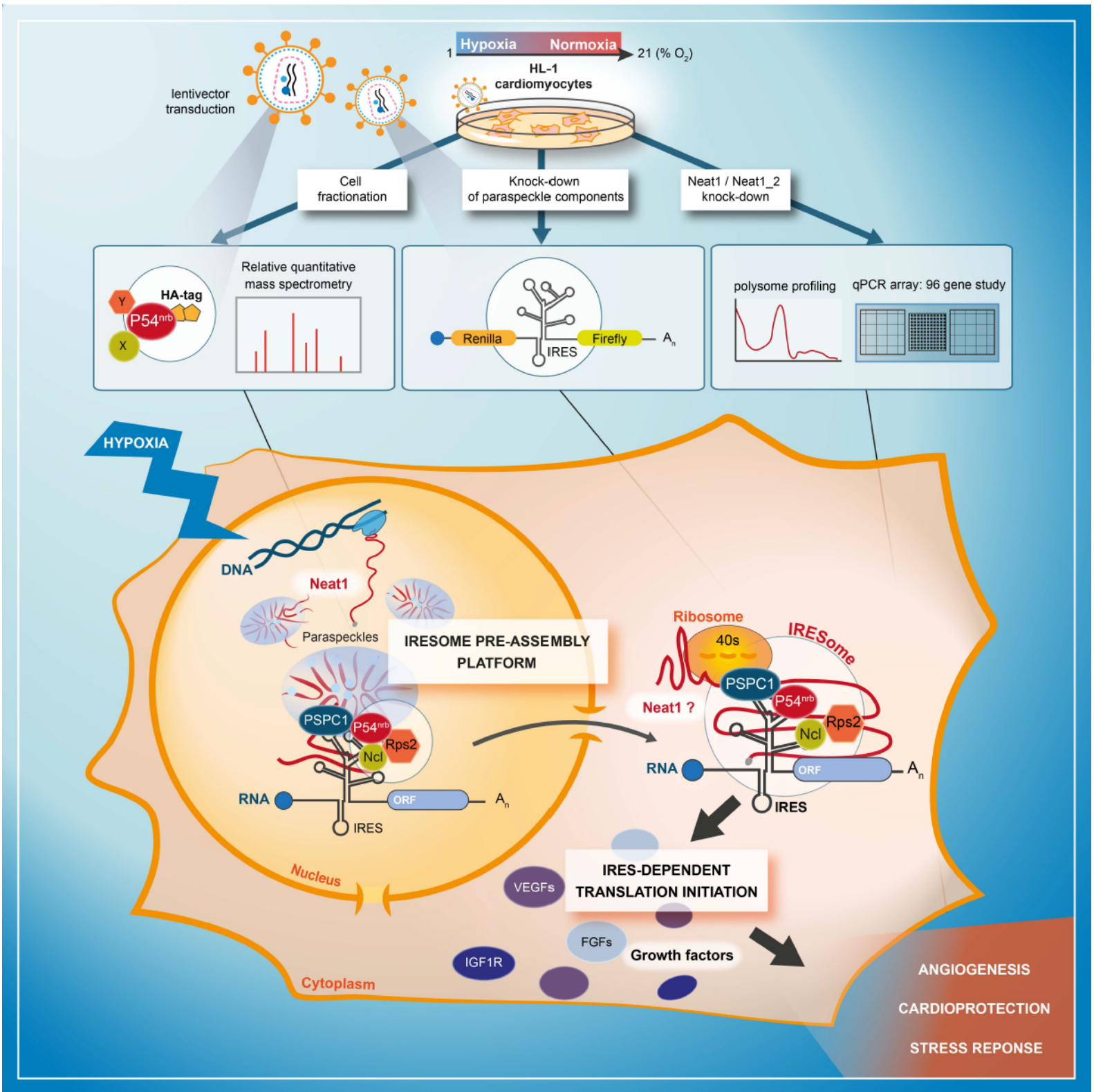


bioRxiv preprint doi: https://doi.org/10.1101/2021.02.10.430272; this version posted February 10, 2021. The copyright holder for this preprint (which was not certified by peer review) is the author/funder, who has granted bioRxiv a license to display the preprint in perpetuity. It is made available under aCC-BY-NC-ND 4.0 International license.

Godet, David, Roussel et al, February 2021

\section{SUMMARY}

Internal ribosome entry sites (IRESs) drive translation initiation during stress. In response to hypoxia, (lymph)angiogenic factors responsible for tissue revascularization in ischemic diseases are induced by the IRES-dependent mechanism. Here we searched for IRES transacting factors (ITAFs) active in early hypoxia in mouse cardiomyocytes. Using knock-down and proteomics approaches, we show a link between a stressed-induced nuclear body, the paraspeckle, and IRES-dependent translation. Our data reveal that the long non-coding RNA Neat1, an essential paraspeckle component, is a key translational regulator, active on IRESs of (lymph)angiogenic and cardioprotective factor mRNAs. In addition, paraspeckle proteins $\mathrm{p} 54^{\mathrm{nrb}}$ and PSPC1 as well as nucleolin and Rps2, two p54 ${ }^{\text {nrb }}$-interacting proteins identified by mass spectrometry, are ITAFs for IRES subgroups. Paraspeckle thus appears as the site of IRESome assembly in the nucleus. Polysome PCR array shows that the Neat1_2 isoform widely affects translation of mRNAs containing IRESs, involved in stress response, angiogenesis or cardioprotection.

\section{KEYWORDS}

IRES, translation, ITAF, non-coding RNA, Neat1, stress, hypoxia, cardiomyocyte

\section{INTRODUCTION}

Cell stress triggers major changes in the control of gene expression at the transcriptional and post-transcriptional levels. One of the main responses to stress is the blockade of global translation allowing cell to save energy. This process results from inactivation of the canonical cap-dependent mechanism of translation initiation (Holcik and Sonenberg, 2005). However, translation of specific mRNAs is maintained or even increased during stress via alternative mechanisms of translation initiation. One of these mechanisms involves internal ribosome entry sites (IRES), structural elements mostly present in the 5' untranslated regions of specific mRNAs, which drive the internal recruitment of ribosomes onto mRNA and promote capindependent translation initiation (Godet et al., 2019).

Hypoxia, or the lack of oxygen, is a major stress occurring in pathologies such as cancer and cardiovascular diseases (Pouysségur et al., 2006). In particular, in ischemic heart failure disease, coronary artery branch occlusion exposes cardiac cells to hypoxic conditions. The cell response to hypoxia induces angiogenesis and lymphangiogenesis to reperfuse the stressed tissue with new vessels and allow cell survival (Morfoisse et al., 2014; Pouysségur et al., 2006; Tatin et al., 2017). The well-known response to hypoxia is the transcriptional induction of specific genes under the control of the hypoxia-induced factors 1 and 2 (HIF1, HIF2) (Hu et al., 2003; Koh et al., 2011). However we have recently reported that most mRNAs coding (lymph)angiogenic growth factors are induced at the translatome level in hypoxic cardiomyocytes (Hantelys et al., 2019). Expression of these factors allows the recovery of functional blood and lymphatic vasculature in ischemic diseases including myocardial infarction (Tatin et al., 2017; YläHerttuala \& Baker, 2017). The mRNAs of the major (lymph)angiogenic growth factors belonging to the fibroblast growth factor (FGF) and vascular endothelial growth factor (VEGF) families all contain IRESs that are activated in early hypoxia (Morfoisse et al., 2014; Hantelys et al., 2019).

IRES-dependent translation is regulated by IRES trans-acting factors (ITAFs) that are in most cases RNA-binding proteins acting as positive or negative regulators. A given ITAF can regulate several IRESs, while a given IRES is often regulated by several ITAFs (Godet et al., 2019), depending on the cell type or physiology. This has led to the concept of IRESome, a multi-partner ribonucleic complex allowing ribosome recruitment onto the mRNA via the IRES. 
bioRxiv preprint doi: https://doi.org/10.1101/2021.02.10.430272; this version posted February 10, 2021. The copyright holder for this preprint (which was not certified by peer review) is the author/funder, who has granted bioRxiv a license to display the preprint in perpetuity. It is made available under aCC-BY-NC-ND 4.0 International license.

Godet, David, Roussel et al, February 2021

ITAFs often exhibit several functions in addition to their ability to control translation. Many of them play a role in alternative splicing, transcription, ribosome biogenesis or RNA stability (Godet et al., 2019). Clearly, a large part of ITAFs are nuclear proteins able to shuttle between nucleus and cytoplasm. Previous data have also shown that a nuclear event is important for cellular IRES activity, leading to the hypothesis of IRESome formation in nucleus (Ainaoui et al., 2015; Semler \& Waterman, 2008; Stoneley et al., 2000).

Interestingly, several ITAFs are components of a nuclear body, the paraspeckle, formed in response to stress (Choudhry et al., 2015; Fox et al., 2002). These ITAFs include several hnRNPs, as well as major paraspeckle proteins such as P54 ${ }^{\text {nrb }}$ nuclear RNA binding (P54 ${ }^{\text {rrb}} / \mathrm{NONO}$ ) and splicing factor proline and glutamine rich (SFPQ/PSF). P54 ${ }^{\text {nrb }}$ and SFPQ belong to the family of drosophila melanogaster behavior and human splicing (DBHS) proteins whose third member is the paraspeckle protein C1 (PSPC1). P54 ${ }^{\text {nrb }}$ and SFPQ are essential for paraspeckle formation while PSPC1 is not. These three DBHS proteins are known to interact with each other and to function in heteroduplexes (Fox et al., 2005; Lee et al., 2015; Passon et al., 2012). In addition, P54 ${ }^{\text {nrb }}$ and SFPQ interact with the long non-coding RNA (lncRNA) Neat1 (nuclear enriched abundant transcript 1), that constitutes the skeleton of the paraspeckle (Clemson et al., 2009; Sunwoo et al., 2009). This lncRNA, a paraspeckle essential component, is present as two isoforms Neat1_1 and Neat1_2 whose sizes in mouse are 3.2 and 20.8 kilobases, respectively (Sunwoo et al., 2009). Its transcription is induced during hypoxia by HIF2 and promotes paraspeckle formation (Choudhry et al., 2015). Neat1 is overexpressed in many cancers (Yang et al., 2017). Recently, its induction by hypoxia has been shown in cardiomyocytes where it plays a role in cell survival (Kenneweg et al., 2019).

According to previous reports, paraspeckle is able to control gene expression via the retention of edited mRNAs and transcription factors (Hirose et al., 2014; Imamura et al., 2014; Prasanth et al., 2005). In 2017, Shen et al. have also shown that the paraspeckle might inhibit translation by sequestering $\mathrm{p} 54^{\text {nrb }}$ and SFPQ which are ITAFs of the c-myc IRES (Shen et al., 2017).

In this study we were interested in finding new ITAFs responsible for the activation of (lymph)angiogenic factor mRNA IRESs in HL-1 cardiomyocytes, during early hypoxia. We have previously shown that the two paraspeckle proteins $\mathrm{p} 54^{\text {nrb }}$ and hnRNPM are ITAFs, activators of the FGF1 IRES during myoblast differentiation (Ainaoui et al., 2015). This incited us to investigate the potential role of the paraspeckle and of Neat1 in the control of IRESdependent translation in hypoxic cardiomyocytes. We show here that Neatl expression and paraspeckle formation are correlated with the activation of the FGF1 IRES during hypoxia. Furthermore the knock-down of $5^{\text {ntrb }}$, PSPC1 or Neat 1 generates a decrease in FGF1 IRES activity and in endogenous FGF1 expression. By quantitative mass spectrometry analysis of the p5 ${ }^{\text {nrb }}$ interactome, we identified two additional ITAFs able to control the FGF1 IRES activity: nucleolin and the ribosomal protein Rps2. Analysis of IRESs in the knock-down experiments showed that $\mathrm{p} 54^{\mathrm{nrb}}$ and PSPC1 are activator of several but not all other IRESs of (lymph)angiogenic and cardioprotective factor mRNAs whereas Neat 1 appears as a strong activator of all the cellular IRESs tested. The data suggest that the paraspeckle, via Neat1 and several protein components would be the site of IRESome assembly in the nucleus. Polysome PCR array reveals that Neat1_2 isoform activates the translation of most IRES-containing mRNAs and of several mRNA families involved in hypoxic response, angiogenesis and cardioprotection.

\section{RESULTS}

FGF1 IRES activation during hypoxia correlates with paraspeckle formation and with Neat1 induction.

In order to analyze the regulation of IRES activity during hypoxia, HL-1 cardiomyocytes were transduced with the "Lucky Luke" bicistronic lentivector validated in our previous reports, containing the renilla luciferase (LucR) and firefly luciferase (LucF) genes separated by the 
bioRxiv preprint doi: https://doi.org/10.1101/2021.02.10.430272; this version posted February 10, 2021. The copyright holder for this preprint (which was not certified by peer review) is the author/funder, who has granted bioRxiv a license to display the preprint in perpetuity. It is made available under aCC-BY-NC-ND 4.0 International license.

Godet, David, Roussel et al, February 2021

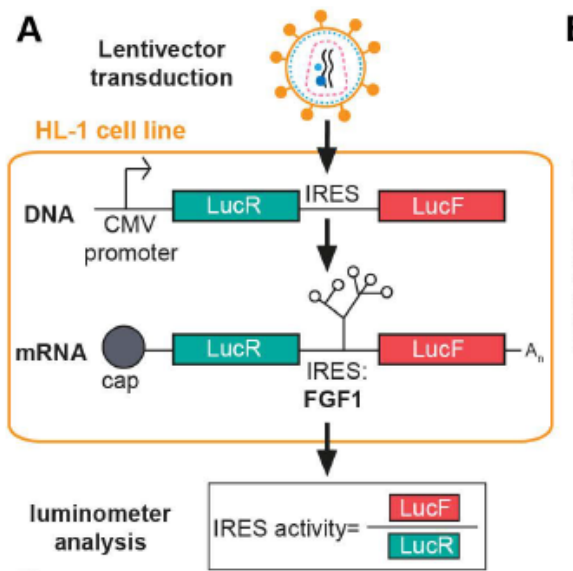

D
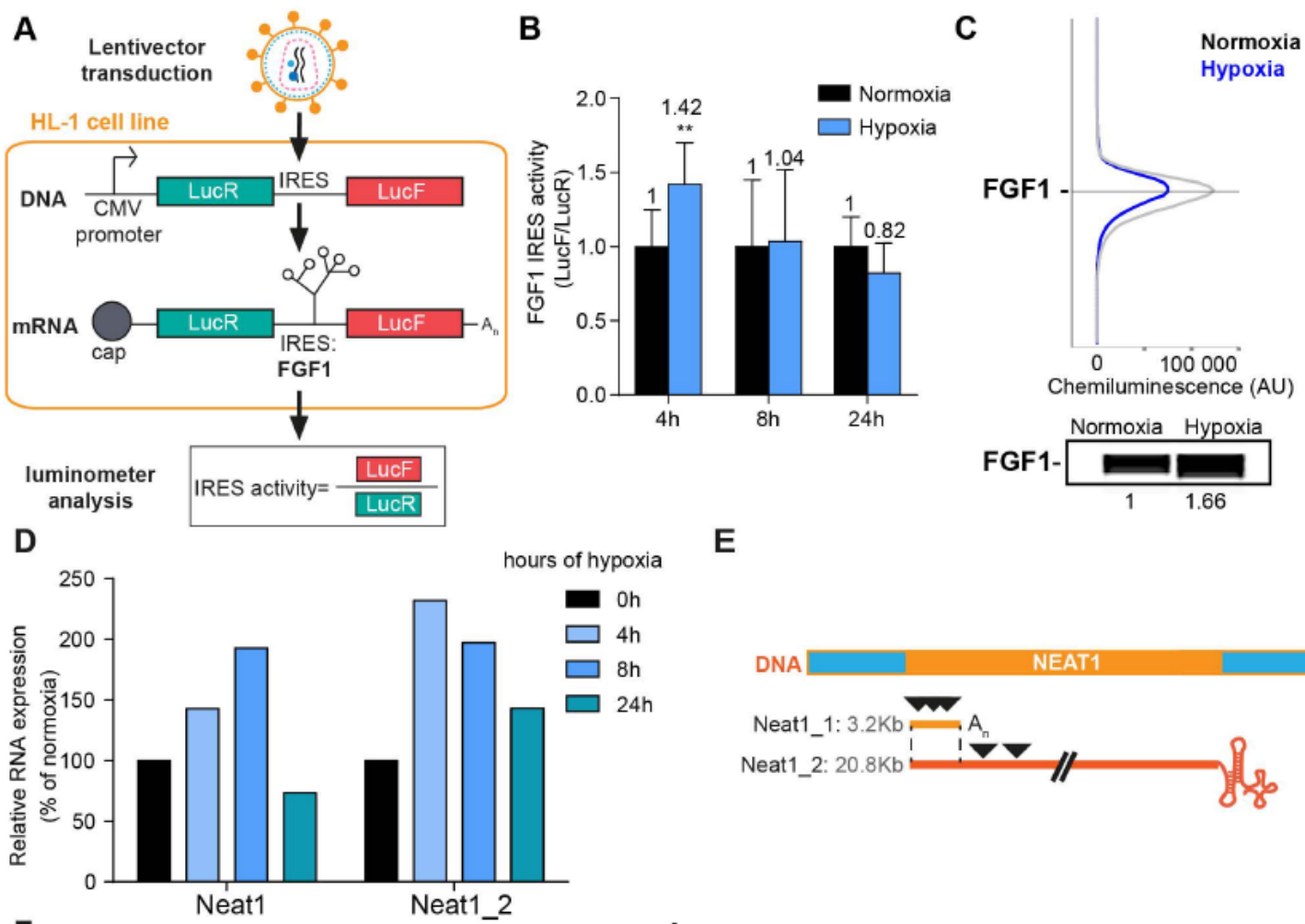

E

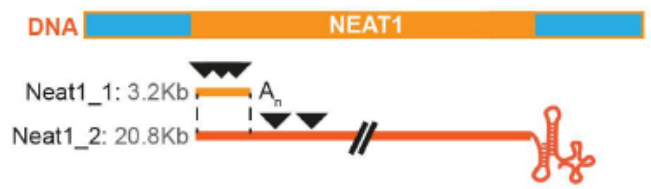

$\mathbf{F}$

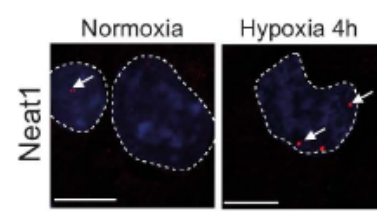

G

H
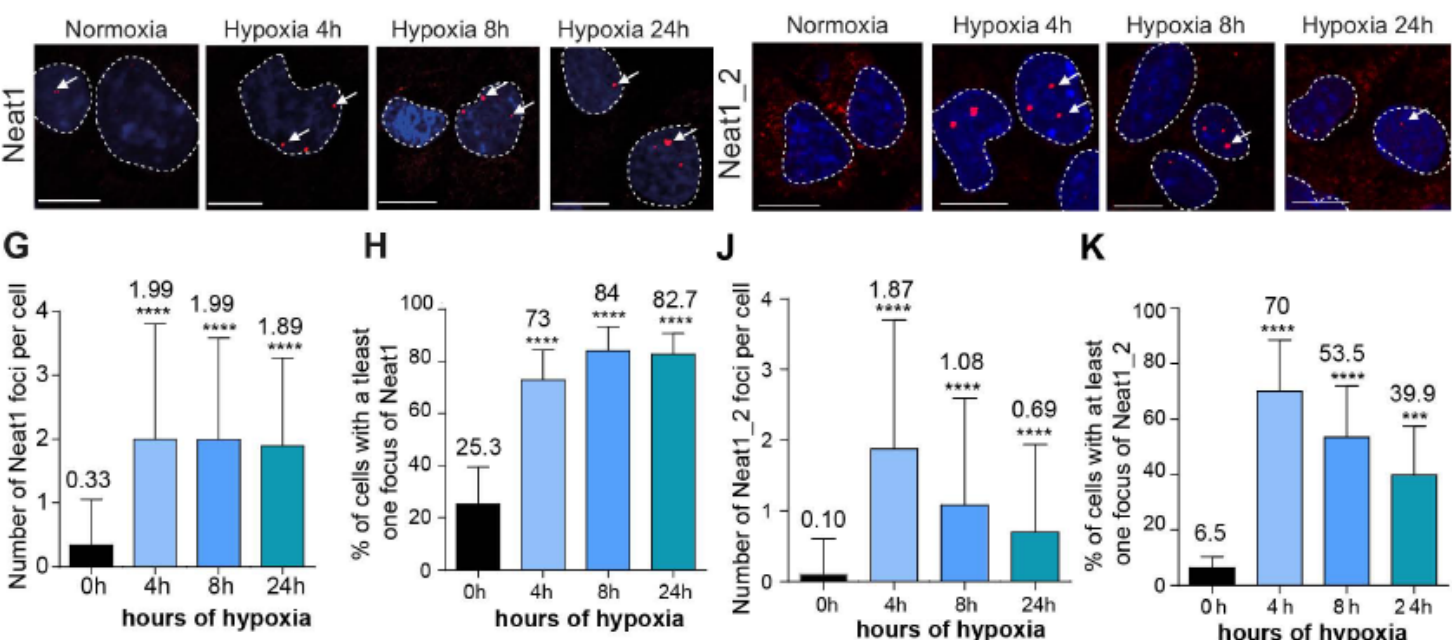

$\mathbf{J}$

K
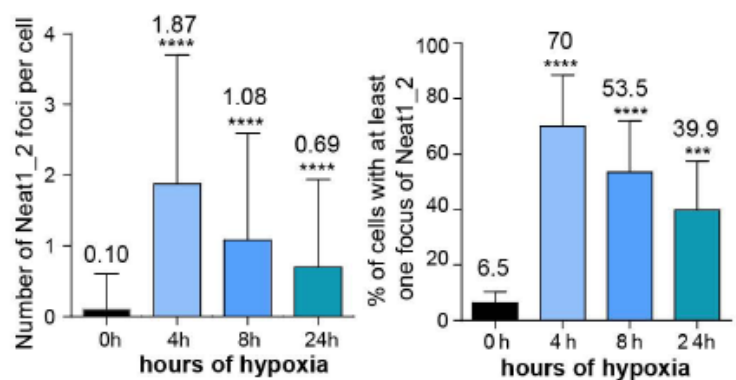

Figure 1. FGF1 IRES activation during hypoxia correlates with Neat1 induction and paraspeckle formation. (A) Schema depicting the Lucky Luke bicitronic construct and HL-1 cell transduced by a lentivector carrying the transgene. The LucF/LucR ratio indicates the IRES activity.

(B) Activity of the human FGF1 IRES in HL-1 cardiomyocytes at $4 \mathrm{~h}, 8 \mathrm{~h}$ or $24 \mathrm{~h}$ of hypoxia normalized to normoxia.

(C) Detection of endogenous mouse FGF1 by capillary Simple Western in normoxic and hypoxic (2 h) cardiomyocytes. The curve corresponds to chemiluminescence signal detected with FGF1 antibody. A numerical blot is represented. Below the blot is shown the quantification of FGF1 normalized to total proteins and to control gapmer. Total proteins are detected by a dedicated channel in capillary Simple Western.

(D) HL-1 cells were subjected to normoxia $(0 \mathrm{~h})$ or to hypoxia during $4 \mathrm{~h}, 8 \mathrm{~h}$ and $24 \mathrm{~h}$. Neat1 and Neat1_2 expression was analyzed by droplet digital PCR (Primer sequences in Table S1). RNA expression is normalized to normoxia time point.

(E) Schema depicting the Neat1 mouse gene and the Neat1_1 and Neat1_2 RNA isoform carrying a poly(A) tail or a triple helix, respectively. Black arrowheads represent FISH probes against Neat1 and Neat1_2 (sequences in Table S1).

(F-K) Neat1 (F) or Neat1_2 (I) FISH labelling in HL-1 cardiomyocytes in normoxia or at $4 \mathrm{~h}, 8 \mathrm{~h}$ and $24 \mathrm{~h}$ of $1 \%$ $\mathrm{O}_{2}$. DAPI staining is represented in blue and Neat1 or Neat1_2 cy3 labelling in red. Nuclei are delimited by dotted lines. Scale bar $=10 \mu \mathrm{m}$.

(G and J) Quantification of Neat1 (G) or Neat1_2 (J) foci per cell by automated counting (ImageJ). 
bioRxiv preprint doi: https://doi.org/10.1101/2021.02.10.430272; this version posted February 10, 2021. The copyright holder for this preprint (which was not certified by peer review) is the author/funder, who has granted bioRxiv a license to display the preprint in perpetuity. It is made available under aCC-BY-NC-ND 4.0 International license.

Godet, David, Roussel et al, February 2021

(H and K) Percentage of cell harboring at least one focus of Neat1 $(\mathrm{H})$ or Neat1_2 (K); Histograms correspond to means \pm standard deviation, with Mann-Whitney $(\mathrm{n}=12)(\mathrm{B})$ or one way ANOV̄ A $(\mathrm{G}-\mathrm{H}, \mathrm{n}=269-453)$ and $(\mathrm{J}-\mathrm{K}$, $\mathrm{n}=342-499) ; * * \mathrm{p}<0.01, * * *<0.001, * * * * \mathrm{p}<0.0001$.

FGF1 IRES (Créancier et al., 2000, Hantelys, 2019) (Fig. 1A). In this construct, the first cistron LucR is expressed in a cap-dependent manner and the second cistron LucF is under the control of the IRES. The ratio LucF/LucR reflects the IRES activity.

The ratios LucF/LucR were measured in HL-1 cells subjected to hypoxia during $4 \mathrm{~h}, 8 \mathrm{~h}$ or 24 $\mathrm{h}$, revealing a significant activation of the FGF1 IRES and induction of endogenous FGF1 after $4 \mathrm{~h}$ of hypoxia, as previously shown (Hantelys et al., 2019) (Fig. 1B and 1C). Neat1 and Neat1_2 expression in cells was measured by reverse transcription and droplet digital PCR (RT ddPCR), showing an increase of Neat 1 and Neat1_2 at $4 \mathrm{~h}$ with a peak of expression of Neat 1 at $8 \mathrm{~h}$ of hypoxia, while the peak of expression of Neat1_2 was observed after $4 \mathrm{~h}$ of hypoxia (Fig. 1D). The same data were also obtained by classical RT-qPCR (data not shown), in agreement with our previous report showing Neat1 induction by hypoxia in HL-1 cells (Hantelys et al., 2019).

In parallel, paraspeckle formation was studied by fluorescent in situ hybridization (FISH) targeting the non-coding RNA Neat 1, considered as the main marker of paraspeckles. The fluorescent probes targeted either the common part of the two Neat1 isoforms, or only the large isoform Neat1_2 (Fig. 1E). After $4 \mathrm{~h}$ of hypoxia, the number of foci increased and reached 2 foci per cell in average, while the number of cells containing at least one focus shifted from $20 \%$ to $70 \%$ (Fig. 1F-K, Fig. S1). This was observed with both Neat1 and Neat1_2 probes. The values observed at $4 \mathrm{~h}$ did not change after $8 \mathrm{~h}$ and $24 \mathrm{~h}$ of hypoxia with the Neatl probe (Fig. 1F-H). In contrast, the number of foci containing Neat 12 decreased after longer times of hypoxia: at $8 \mathrm{~h}$ and $24 \mathrm{~h}$, the number of foci per cell reached 1 and 0.5 while only $50 \%$ and $40 \%$ of the cells contained at least one focus, respectively (Fig. 1I-K).

These data revealed that FGF1 IRES activation correlates with the increase in Neat 1 expression and paraspeckle formation after $4 \mathrm{~h}$ of hypoxia in HL-1 cardiomyocytes. This correlation fits better with Neat1_2 than with the total Neat1, suggesting a link between expression of the long Neat1 isoform and IRES activation.

\section{LncRNA Neat1 knock-down drastically affects the FGF1 IRES activity and endogenous FGF1 expression.}

To determine whether Neat1 could have a role in the regulation of FGF1 IRES activity, we depleted HL-1 for this non-coding RNA using locked nucleic acid (LNA) gapmers, antisense modified oligonucleotides described for their efficiency in knocking-down nuclear RNAs. HL1 cells transduced with the bicistronic vector were transfected with a pool of gapmer targeting Neat1 and with a control gapmer (Table S1). The knock-down efficiency was measured by smiFISH and ddPCR and showed a decrease in the number of paraspeckle, which shifted from 5 to 2 foci per cell (Fig. 2A-B, Fig. S2). In these experiments the number of paraspeckles was high in normoxia (almost 5 foci per cell), suggesting that cells were already stressed by the gapmer treatment, before being submitted to hypoxia.

To evaluate the IRES activity, the ratio LucF/LucR was measured in normoxia or after $4 \mathrm{~h}$ of hypoxia, revealing that the IRES activity decreased by two times upon Neat1 depletion (Fig. 2C, Table S2). This effect was also observed on endogenous FGF1 protein expression, measured by capillary Simple Western, which decreased by three times (Fig. 2D).

These data suggested that Neat1 regulates FGF1 expression, and acts as an ITAF of the FGF1 IRES. 
bioRxiv preprint doi: https://doi.org/10.1101/2021.02.10.430272; this version posted February 10, 2021. The copyright holder for this preprint (which was not certified by peer review) is the author/funder, who has granted bioRxiv a license to display the preprint in perpetuity. It is made available under aCC-BY-NC-ND 4.0 International license.

Godet, David, Roussel et al, February 2021

A
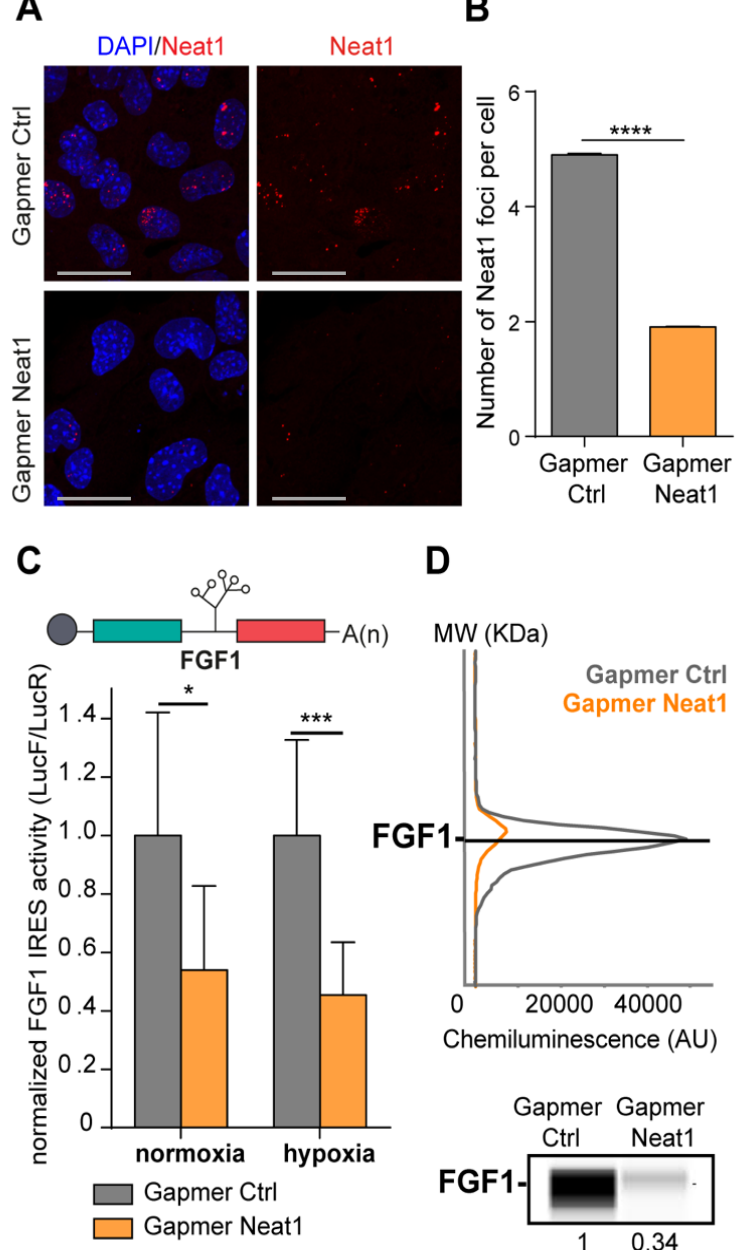

D

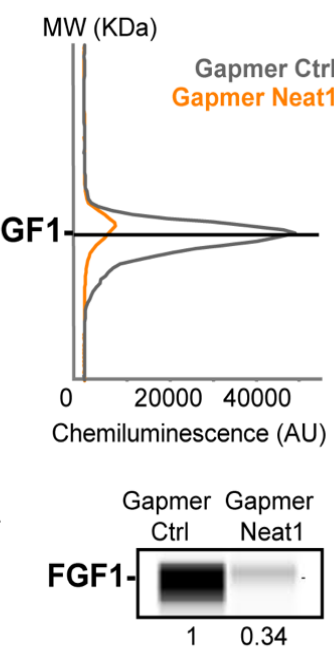

Figure 2. LncRNA NEAT1 knock-down drastically affects the FGF1 IRES activity and endogenous FGF1 expression.

(A) SmiFISH imaging of Neat1 knock-down by a pool of gapmers targeting both isoforms (Sequences in Table S1C). Scale bar $=10 \mu \mathrm{m}$

(B) Neat1 foci counting per cell for the control gapmer and Neat1 LNA gapmer pool, using unpaired two-tailed student $t$-test with $n=249$ for control and 187 for Neat1 gapmer LNA.

(C) FGF1 IRES activities in HL-1 cells transduced with Lucky Luke bicistronic reporter and treated with gapmer Neat 1 or control during normoxia or hypoxia $\left(1 \% \mathrm{O}_{2}\right)$. Histograms correspond to means \pm standard deviation of the mean. Non parametric Mann-Withney test was performed with $\mathrm{n}=9 . \quad * \mathrm{p}<0.05, \quad * * *<0.001$, $* * * * p<0.0001$. For each IRES the mean has been calculated with nine cell culture biological replicates, each of them being already the mean of three technical replicates $(27$ technical replicates in total). Detailed values of biological replicates are presented in Table S2.

(D) Detection of endogenous mouse FGF1 by capillary Simple Western. The curve corresponds to chemiluminescence signal detected with FGF1 antibody. A numerical blot is represented. Below the blot is shown the quantification of FGF1 normalized to total proteins and to control gapmer. Total proteins are detected by a dedicated channel in capillary Simple Western.

\section{Paraspeckle proteins P54 ${ }^{\text {nrb }}$ and PSCP1, but not SFPQ, are ITAFs of the FGF1 IRES.}

The correlation between paraspeckle formation and FGF1 IRES activation incited us to study the role of other paraspeckle components in the control of IRES activity. Three major paraspeckle proteins were chosen, the DBHS proteins, SFPQ, p54 ${ }^{\text {nrb }}$ and PSPC1 (Fig. 3A). SFPQ and p54 ${ }^{\text {nrb }}$ have been previously described for their ITAF function (Ainaoui et al., 2015; Cobbold et al., 2008; Lampe et al., 2018; Sharathchandra et al., 2012; Shen et al., 2017). In particular, p54 ${ }^{\text {nrb }}$ regulates the FGF1 IRES activity during myoblast differentiation (Ainaoui et al, 2015).

HL-1 cells transduced by the "Lucky Luke" bicistronic construct were transfected with siRNA smartpools targeting each of the three proteins. The knock-down efficiency was checked by capillary Simple Western, classical Western or RT qPCR (Fig. S3).

SFPQ knock-down did not affect the IRES activity (Fig. 3B, Table S3). In contrast, we observed a decrease in IRES activity with p54 ${ }^{\text {nrb }}$ and PSPC1 knock-down, both in normoxia and in hypoxia (Fig. 3C-D, Tables S4 and S5), despite a knock-down efficiency below 50\%. p54 ${ }^{\text {nrb }}$ and PSPC1 knock-down also inhibited the expression of endogenous FGF1 protein (Fig. 3E-F). These data confirmed the ITAF role of $\mathrm{p} 54^{\text {nrb }}$ in HL-1 cardiomyocyte, and indicated that PSPC1 is also an ITAF of the FGF1 IRES. The ability of three paraspeckle components, Neat1, p54 nrb and PSPC1 to regulate the FGF1 IRES activity led us to the hypothesis that the paraspeckle might be involved in the control of IRES-dependent translation. 
bioRxiv preprint doi: https://doi.org/10.1101/2021.02.10.430272; this version posted February 10, 2021. The copyright holder for this preprint (which was not certified by peer review) is the author/funder, who has granted bioRxiv a license to display the preprint in perpetuity. It is made available under aCC-BY-NC-ND 4.0 International license.

Godet, David, Roussel et al, February 2021

A

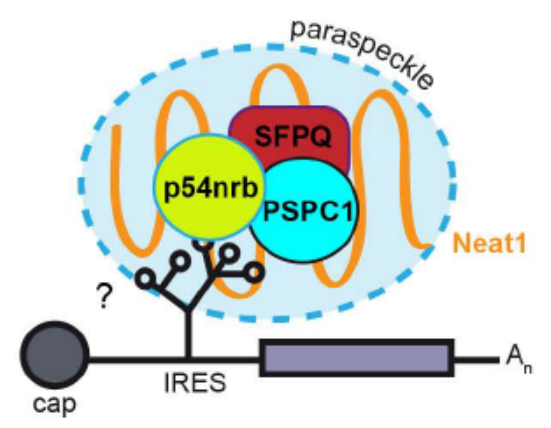

C

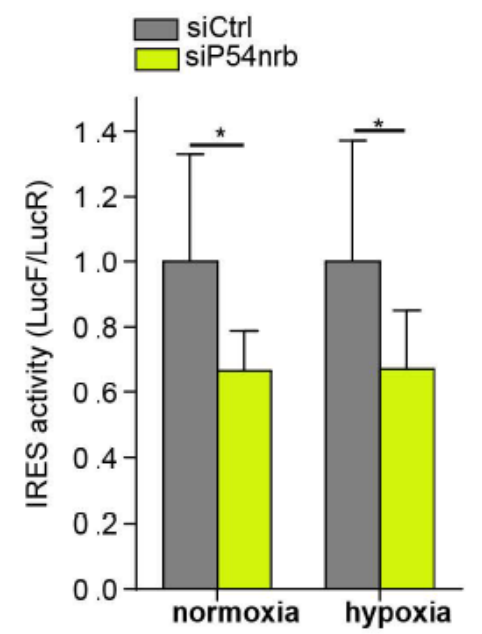

E
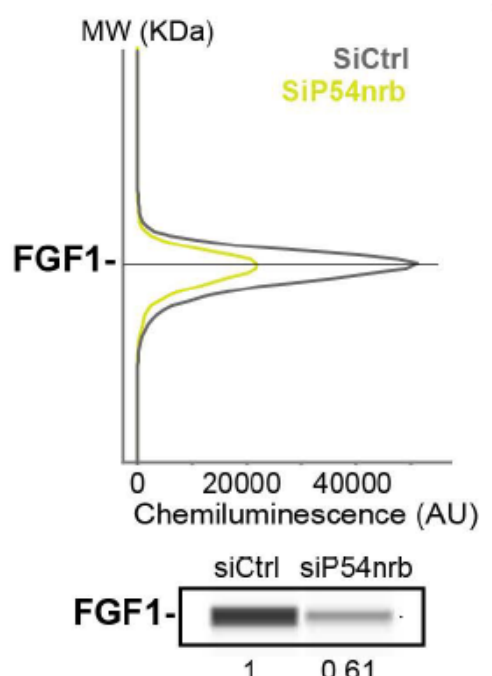

B

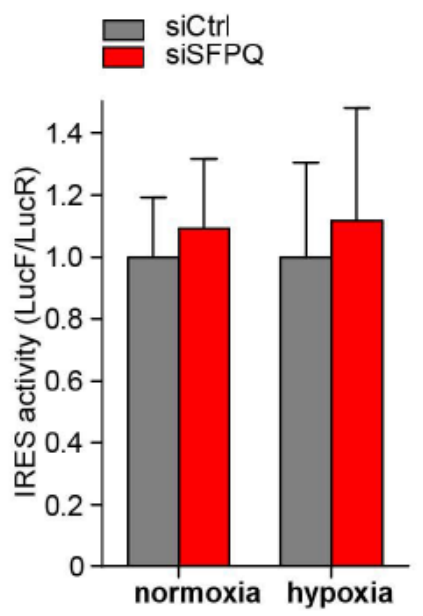

D

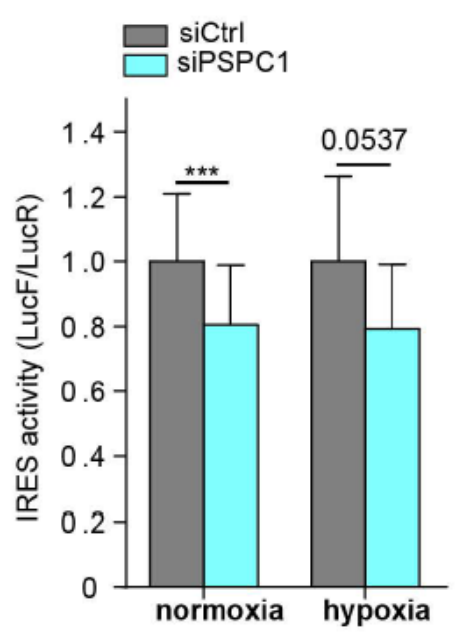

$\mathbf{F}$

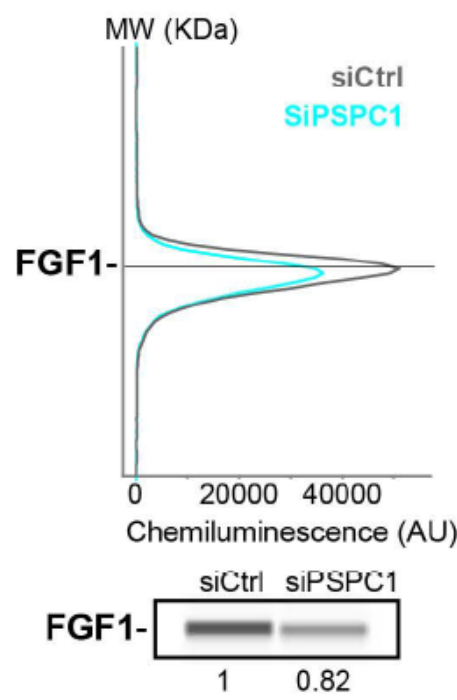

Figure 3. Paraspeckle proteins p54 ${ }^{\text {nrb }}$ and PSCP1, but not SFPQ, are ITAFs of the FGF1 IRES.

(A) Schema of paraspeckle and DBHS proteins possibly bound to an IRES-containing mRNA. (B-D) FGF1 IRES activity upon knock-down of SFPQ (B), P54 ${ }^{\text {nrb }}(\mathrm{C})$ or PSPC1 (D) in HL1 cell transduced with Lucky Luke bicistronic reporter during normoxia or hypoxia was measured as in Figure 2. Cells were harvested $72 \mathrm{~h}$ after siRNA treatment. The IRES activity values have been normalized to the control siRNA. Histograms correspond to means \pm standard deviation of the mean, with a non parametric Mann-Whitney test with $\mathrm{n}=9 ; \quad * \mathrm{p}<0.05$, $* * *<0.001$. For each IRES the mean has been calculated with nine cell culture biological replicates, each of them being already the mean of three technical replicates (27 technical replicates in total). Detailed values of biological replicates are presented in Tables S3, S4 and S5.

(E and F) Capillary Simple Western detection of endogenous FGF1 protein with P54 ${ }^{\text {nrb }}(\mathrm{E})$ or PSPC1 (F) knockdown.

\section{$\mathbf{P 5 4} 4^{\mathrm{nrb}}$ interactome in normoxic and in hypoxic cardiomyocytes.}

The moderate effect of $\mathrm{p} 54^{\mathrm{nrb}}$ or PSPC1 depletion on FGF1 IRES activity suggested that other proteins are involved. In addition, previous data from the literature support the hypothesis that the IRESome is a multi-partner complex. In order to identify other members of this complex, we analysed the p54 ${ }^{\text {nrb }}$ interactome in HL-1 cell nucleus and cytoplasm using a label-free quantitative mass spectrometry approach. For this purpose, cells were transduced by a 
bioRxiv preprint doi: https://doi.org/10.1101/2021.02.10.430272; this version posted February 10, 2021. The copyright holder for this preprint (which was not certified by peer review) is the author/funder, who has granted bioRxiv a license to display the preprint in perpetuity. It is made available under aCC-BY-NC-ND 4.0 International license.

\section{Godet, David, Roussel et al, February 2021}

lentivector expressing an HA-tagged p54 ${ }^{\text {nrb }}$ (Fig. 4A). After cell fractionation (Fig. 4B), protein complexes from normoxic and hypoxic cells were immunoprecipitated with anti-HA antibody. Immunoprecipitated interacting proteins (three to four biological replicates for each group) were isolated by SDS-PAGE, in-gel digested with trypsin and analysed by nano-liquid chromatography-tandem mass spectrometry (nanoLC-MS/MS), leading to the identification and quantification of 2013 proteins (Table S6). To evaluate $\mathrm{p} 54^{\mathrm{nrb}}$ interaction changes, pairwise

A

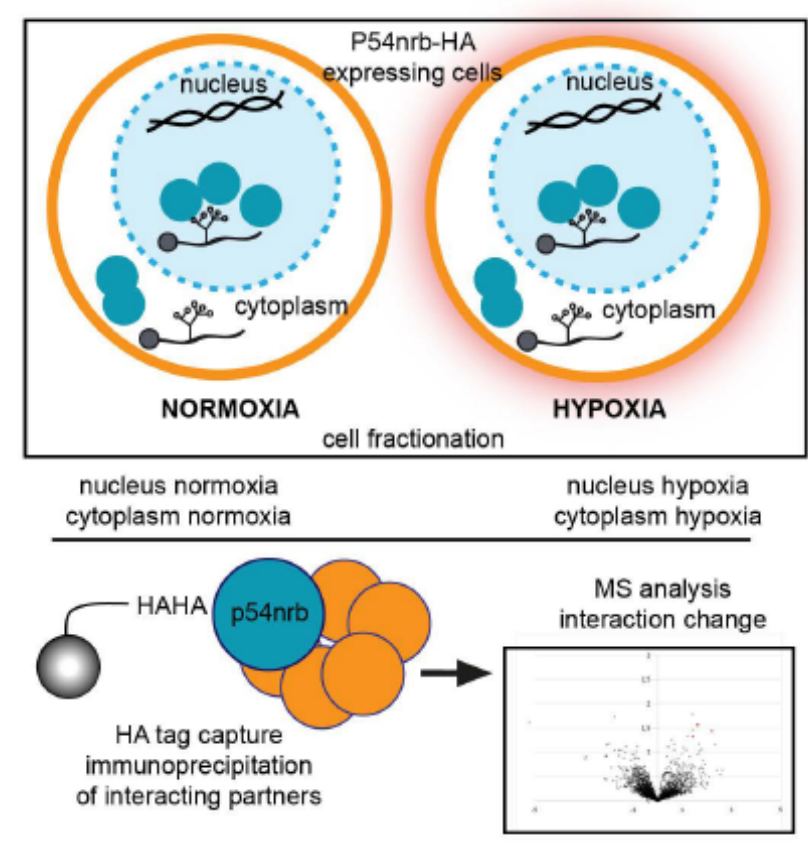

B

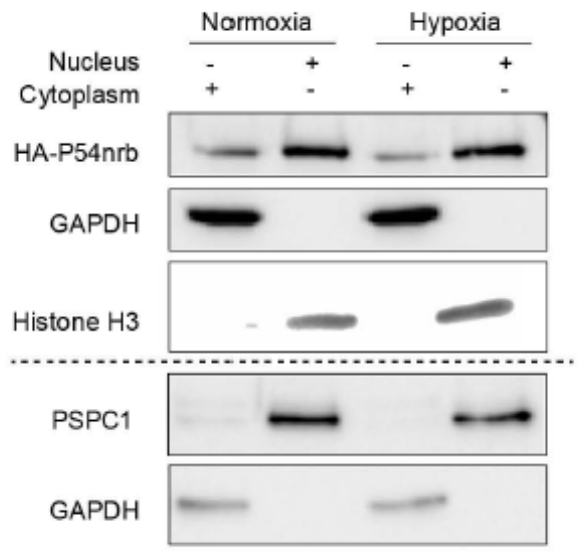

C

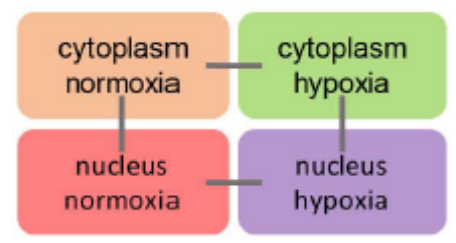

D

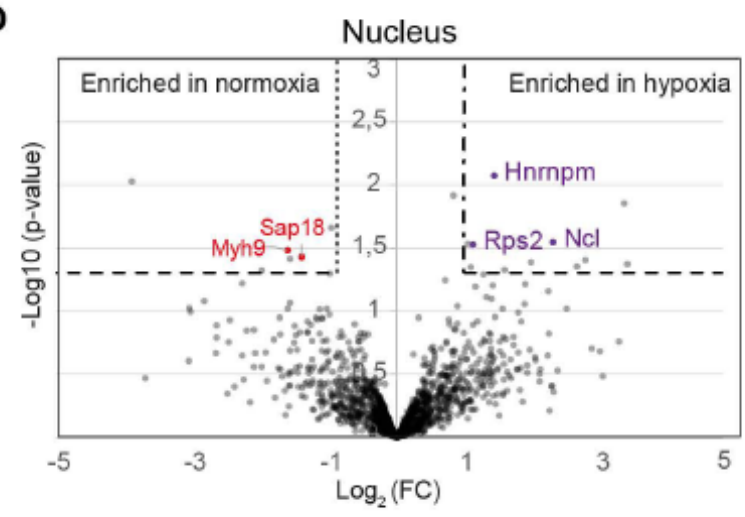

E

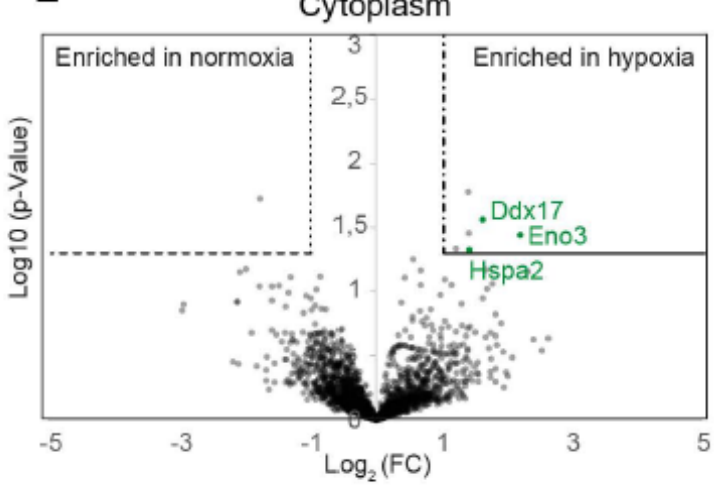

Figure 4. $P 54^{\text {nrb }}$ interactome in normoxic and in hypoxic cardiomyocytes.

(A) Experimental workflow : p5 $4^{\text {nrb }}$-HA transduced HL-1 cells were subjected to normoxia or hypoxia, then nucleus and cytoplasm fractionation was performed and extracts were immunoprecipitated using anti-HA antibody. Enriched interacting proteins were identified by using a label-free quantitative mass spectrometry approach.

(B) Western blot of fractionation experiment of HL-1 cell in normoxia and hypoxia. Histone H3 was used as a nuclear control and GAPDH as a cytoplasm control. The dotted line delineates two different blots of the same fractionation experiment.

(C) Schema of the four pairwise comparisons submitted to statistical analysis.

(D and E) Volcano plots showing proteins significantly enriched in the nucleus for hypoxia (purple) versus normoxia (red) (D) or in the cytoplasm for hypoxia (green) versus normoxia (E). An unpaired bilateral student ttest with equal variance was used. Enrichment significance thresholds are represented by an absolute $\log 2-$ transformed fold-change $(\mathrm{FC})$ greater than 1 and a - $\log 10$-transformed (p-value) greater than 1.3. 
bioRxiv preprint doi: https://doi.org/10.1101/2021.02.10.430272; this version posted February 10, 2021. The copyright holder for this preprint (which was not certified by peer review) is the author/funder, who has granted bioRxiv a license to display the preprint in perpetuity. It is made available under aCC-BY-NC-ND 4.0 International license.

Godet, David, Roussel et al, February 2021

comparisons based on MS intensity values were performed for each quantified proteins between the four groups, cytoplasmic and nuclear complexes from cells subjected to normoxia or hypoxia (Fig. 4C). Enriched proteins were selected based on their significant protein abundance variations between the two compared group (fold-change $(\mathrm{FC})>2$ and $<0.5$, and Student $t$ test $\mathrm{P}<0.05$ ) (see STAR Method for details) (Fig. 4D, Fig. 4E and Fig. S4). Globally, the HA-tag capture revealed an enrichment of hnRNP in nucleus and of ribosomal proteins in cytoplasm (Fig S4A-B). In nucleus P54 ${ }^{\text {nrb }}$ also interacted with itself (endogenous mouse Nono), PSPC1 and SFPQ, as well as with other paraspeckle components and ITAFs such as hnRNPA1, hnRNPC, hnRNPI and hnRNPK (Fig. S4A)(Godet et al., 2019). As regards cytoplasmic proteins, we identified Rps25, a ribosomal protein previously described as an ITAF for many IRESs (Fig. S4A)(Hertz et al., 2013). Interestingly, p54 ${ }^{\text {nrb }}$ also interacted with Rps5, Rps 18 and Rps19, and other Rps, mainly from the small ribosome subunit. Only few proteins were enriched when comparing hypoxic versus normoxic extracts. In hypoxic nucleus the enriched proteins are hnRNPM, nucleolin (both previously described as ITAFs) (Hertz et al., 2013; Shi et al., 2016, 2017) and the ribosomal protein Rps2/uS5 (Fig. 4D), while the helicase Ddx17, the enolase Eno3 and the heat shock protein Hspa2 are enriched in hypoxic cytoplasm (Fig 4E). These data showed that $\mathrm{p} 54^{\mathrm{nrb}}$ interacts in normoxia and hypoxia with several ITAFs known as paraspeckle components, suggesting that the paraspeckle might be involved in the formation of the IRESome. Its interaction with numerous Rps also suggests that it interacts with the small ribosome subunit in the cytoplasm.

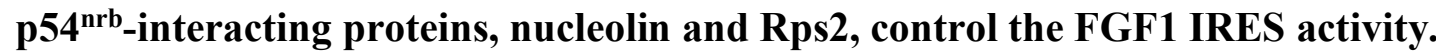

The three candidates identified in nuclear extracts of hypoxic cardiomyocytes, hnRNPM, nucleolin and Rps2 represent potential candidates as ITAFs of the FGF1 IRES in hypoxia. Among them, hnRNPM has been previously described as an ITAF during myoblast

A

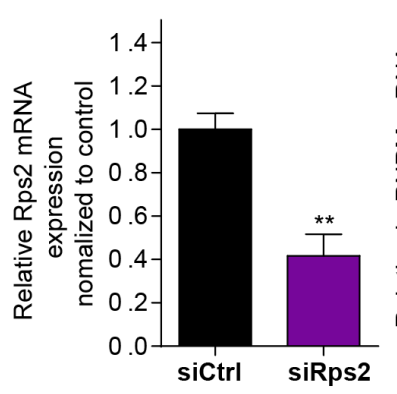

$\mathbf{E}$
B
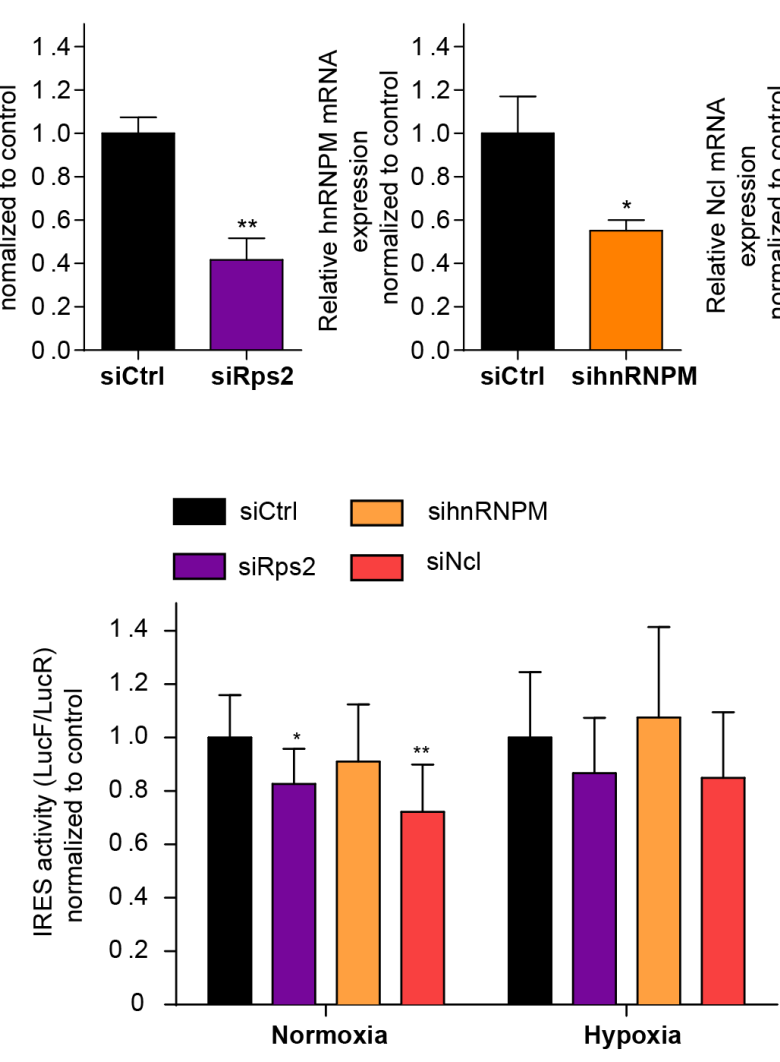

C

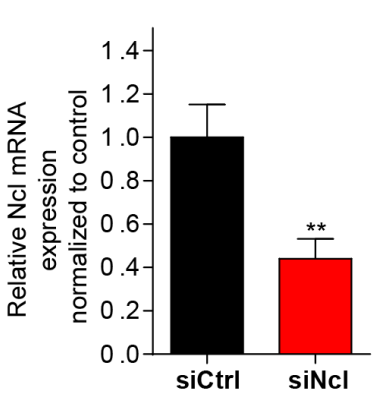

$\mathbf{F}$

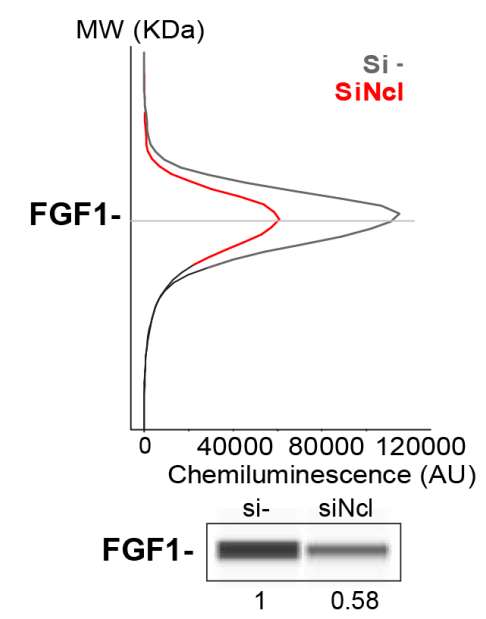

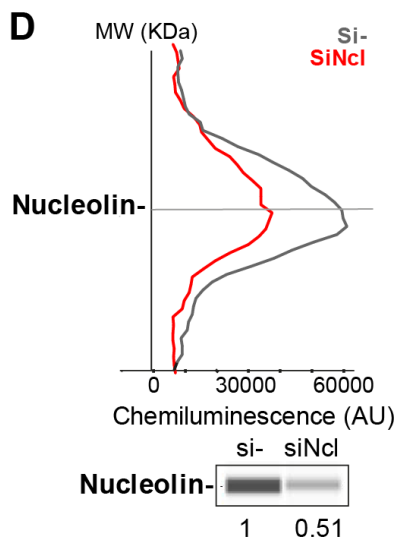


bioRxiv preprint doi: https://doi.org/10.1101/2021.02.10.430272; this version posted February 10, 2021. The copyright holder for this preprint (which was not certified by peer review) is the author/funder, who has granted bioRxiv a license to display the preprint in perpetuity. It is made available under aCC-BY-NC-ND 4.0 International license.

Godet, David, Roussel et al, February 2021

Figure 5. p54 $^{\text {nrb }}$-interacting proteins, nucleolin and Rps2, control the FGF1 IRES activity.

(A-C) Quantification of Rps2 (A), hnRNPM (B) and nucleolin (C) RNA expression in HL-1 cells transfected with siRNAs against Rps2, hnRNPM or nucleolin, respectively. RNA expression was measured by RT-qPCR and normalized to control siRNA. One representative experiment is shown with $n=3$ biological replicates. Student twotailed t-test was performed with $\mathrm{n}=3$ of for $\mathrm{E}$ Mann-Whitney test with $\mathrm{n}=9 ;{ }^{*} \mathrm{p}<0.05, * * \mathrm{p}<0.01, * * *<0.001$, $* * * * \mathrm{p}<0.0001$

(D) Capillary Simple Western of nucleolin following nucleolin knock-down.

(E) FGF1 IRES activity with knock-down by siRNA interference of candidate ITAF nucleolin in HL-1 in normoxia or hypoxia $1 \% \mathrm{O}_{2}$ was performed as in Figure 2. The IRES activity values have been normalized to the control siRNA. Histograms correspond to means + standard deviation of the mean, with a non parametric MannWhitney test $* p<0.05, * * p<0.01$. For each IRES the mean has been calculated with nine cell culture biological replicates, each of them being already the mean of three technical replicates (27 technical replicates in total but the $\mathrm{M}-\mathrm{W}$ test was performed with $\mathrm{n}=9$ ). Detailed values of biological replicates are presented in Table S5.

(F) Capillary Simple Western of endogenous FGF1 following nucleolin knock-down. Histograms correspond to means \pm standard deviation.

differentiation while nucleolin is an ITAF of several IRESs including p53 and VEGFD IRESs but has never been described for FGF1 (Ainaoui et al., 2015; Chen et al., 2012; Godet et al., 2019; Morfoisse et al., 2016; Peddigari et al., 2013; Takagi et al., 2005).

HL-1 cardiomyocytes transduced by the Lucky Luke lentivector with the FGF1 IRES were transfected as above with siRNA smartpools targeting Rps2, hnRNPM or nucleolin (Fig. 5). The knock-down was effective, but only 50-60\%, for the three mRNAs (Fig. 5A-D). This moderate knock-down was probably due to a weak transfection efficiency of HL-1 cells with the siRNAs. Nevertheless, we observed a decrease in IRES activity upon depletion of Rps2 and nucleolin, significant in normoxia but with the same trend in hypoxia while no effect was observed upon hnRNPM depletion (Fig. 5E, Table S3). Nucleolin depletion inhibited endogenous FGF1 protein expression (Fig. 5F). These data suggest that nucleolin and Rps2 are new ITAFs of the FGF1 IRES. Their nuclear localization and their interaction with $\mathrm{p} 54^{\mathrm{nrb}}$ indicate that they could be component of the paraspeckle. Rps2 has never been described as an ITAF before the present study.

Neat1 is the key activator of (lymph)angiogenic and cardioprotective factor mRNA IRESs. We have shown above that three main paraspeckle components, Neat1, p54 nrb and PSPC1, control the FGF1 IRES activity in HL-1 cardiomyocytes. To determine if a role of paraspeckle in translational control may be generalized to other IRESs, we used Lucky Luke lentivectors containing a set of other IRESs between the two luciferase genes (Fig. 6). HL-1 cells were transduced by the different lentivectors and transfected either by the siRNA smartpools to deplete $\mathrm{p} 54^{\mathrm{nrb}}$ and PSPC1, or by the gapmer pool to deplete Neat1. The data revealed that $\mathrm{p} 54^{\mathrm{nrb}}$ or PSPC1 depletion affected several IRESs but not all (Fig. 6A-B, Tables S4 and S5), whereas Neat1 depletion clearly affected all cellular IRESs but not the viral EMCV IRES (Fig. 6C, Table S2).

These data allowed us to regroup the IRESs in different "regulons" in normoxia and in hypoxia (Fig. 6D). According to our data, P54 $4^{\text {nrb }}$ is an activator of the FGF1 and VEGFC IRESs in normoxia, and of the FGF1 and VEGFAa IRESs in hypoxia. PSPC1 is an activator of the FGF1, FGF2, VEGFAa, VEGFC and IGF1R IRESs in normoxia and of the FGF1 and FGF2 IRESs in hypoxia. Neat1 is an activator of the FGF1, FGF2, VEGFAb, VEGFC, VEGFD, IGF1R and cmyc IRESs but not of the VEGFAa IRES in normoxia while it activates all the cellular IRESs in hypoxia. The EMCV IRES does not belong to any of these groups as it is not regulated by these three ITAFs, suggesting that this viral IRES is not regulated by the paraspeckle.

In conclusion, these data suggest that IRESome composition varies for each IRES and with the normoxic or hypoxic conditions. The long non-coding RNA Neat 1 appears as the key ITAF for the activation of all the cellular IRESs, suggesting a crucial role of the paraspeckle in IRESome formation and in the control of IRES-dependent translation, at least for cellular IRESs. 
bioRxiv preprint doi: https://doi.org/10.1101/2021.02.10.430272; this version posted February $10,2021$. The copyright holder for this preprint (which was not certified by peer review) is the author/funder, who has granted bioRxiv a license to display the preprint in perpetuity. It is made available under aCC-BY-NC-ND 4.0 International license.

Godet, David, Roussel et al, February 2021

A

$\square \operatorname{siP} 54 \mathrm{nrb}$

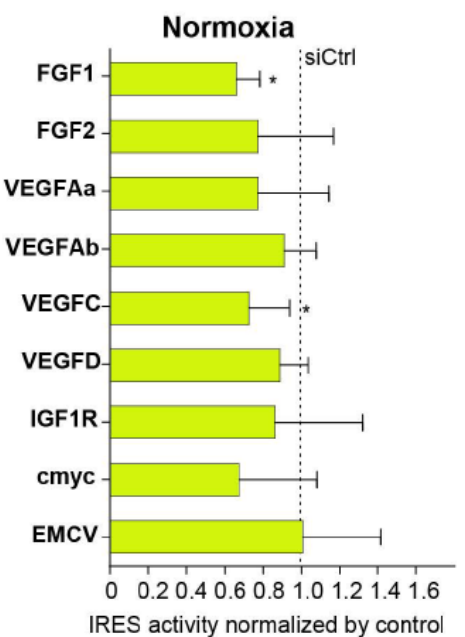

Hypoxia

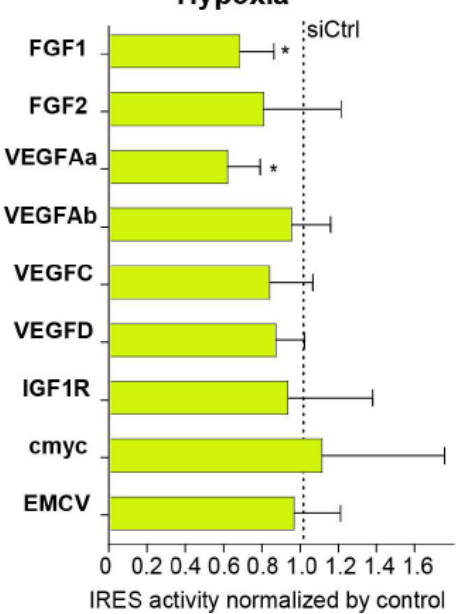

B $\square \operatorname{siPSPC} 1$
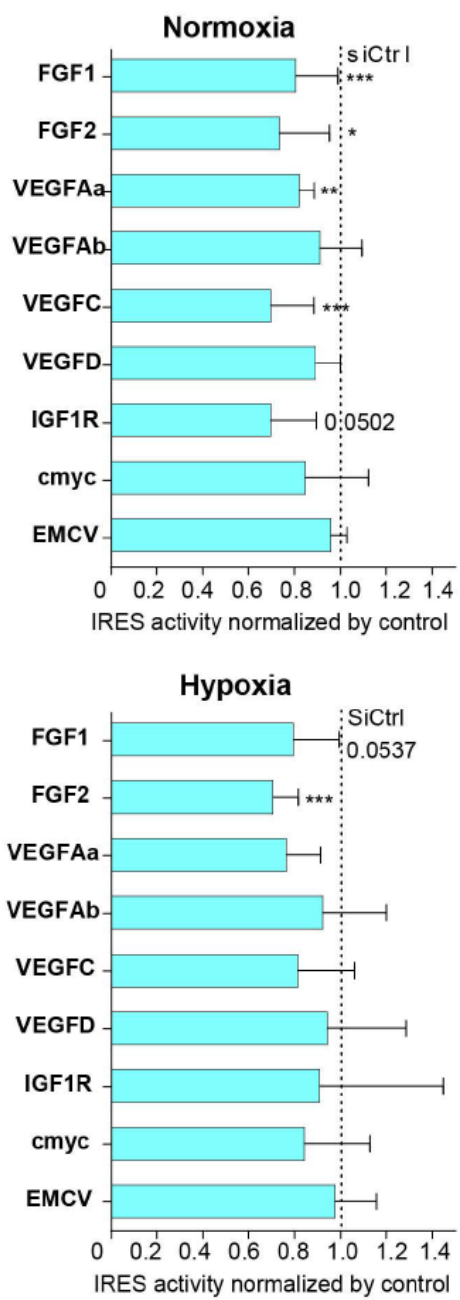

C $\square$ LNA gapmer Neat1
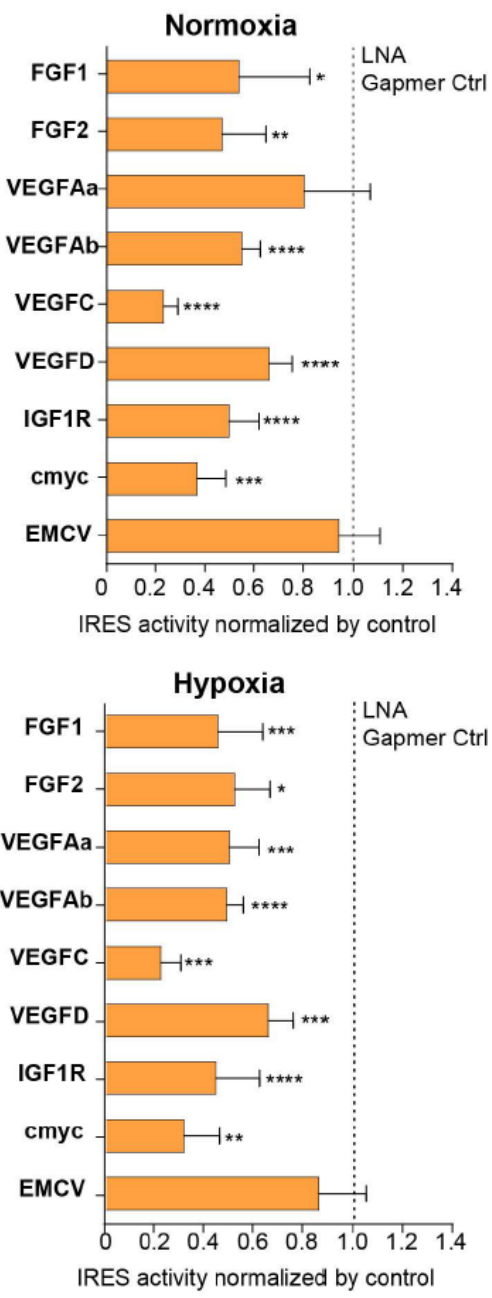

D

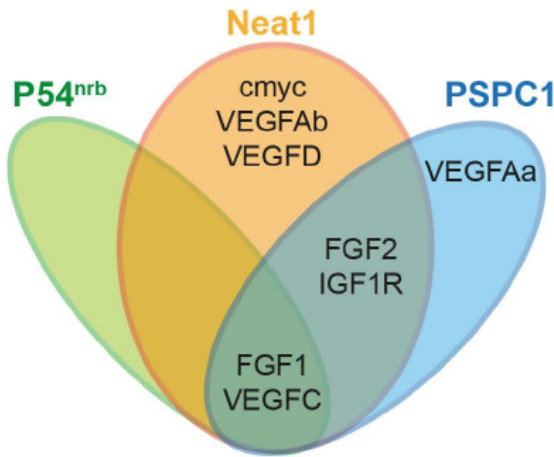

Normoxia

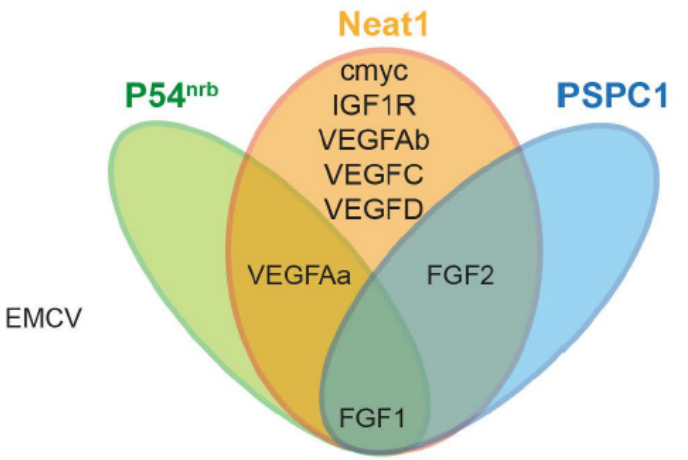

Hypoxia

Figure 6. Neat1 is the key activator of (lymph)angiogenic and cardioprotective factor mRNA IRESs.

(A-C) HL-1 subjected to normoxia or $1 \% \mathrm{O}_{2}$ hypoxia were transduced by Lucky Luke bicistronic lentivectors with FGF1, FGF2, VEGFAa, VEGFAb, VEGFC, VEGFD, IGF1R, c-myc or EMCV IRES, then the knock-down of p54 ${ }^{\text {nrb }}(\mathrm{A})$ PCPC1 (B) and Neat1 (C) was performed as in Fig. 2 and Fig. 3. IRES activities were measured and normalized to activities in normoxia. IRES activity in normoxia is represented by a dotted line at 1 . Histograms correspond to means + standard deviation, and Mann-Whitney test with $n=9$ or $n=12$ for FGF1 IRES; *p $<0.05$, $* * \mathrm{p}<0.01, * * *<0.001,{ }^{*} * * * \mathrm{p}<0.0001$. For each IRES the mean has been calculated with nine cell culture biological replicates, each of them being already the mean of three technical replicates (27 technical replicates in total). Detailed values of biological replicates are presented in Tables S2, S3 and S4.

(D) Schema depicting groups of IRESs regulated by Neat1, PSPC1 or P54nrb in normoxia or hypoxia. 
bioRxiv preprint doi: https://doi.org/10.1101/2021.02.10.430272; this version posted February 10, 2021. The copyright holder for this preprint (which was not certified by peer review) is the author/funder, who has granted bioRxiv a license to display the preprint in perpetuity. It is made available under aCC-BY-NC-ND 4.0 International license.

Godet, David, Roussel et al, February 2021

\section{Neat1_2 is a translational activator of genes involved in the stress response.}

The role of Neat- 1 on translatome was then studied using a Fluidigm Deltagene PCR array targeting 96 genes coding IRES-containing mRNAs, ITAFs or proteins involved in angiogenesis and cardioprotection (Table S1E). HL-1 cells were treated with gapmers targeting the two Neat1 isoforms or only Neat1_2, before analyzing the recruitment of mRNAs into polysomes compared to control gapmer. Recruitment into polysomes decreased for $49 \%$ of IRES-containing mRNAs following Neat 1 invalidation, whereas this decrease concerned $95 \%$ of these mRNAs after Neat1_2 knock-down (Fig. 7A and 7B, Table S7). In contrast, the global level of translation was not affected (Fig. S5). This suggested that the ITAF role of Neat1 may be generalized to most IRESs (regarding cellular mRNAs), and that the Neat1_2 isoform is probably responsible for this. Interestingly, a similar effect was observed for the other genes tested in the PCR array: Neat1 or Neat1_2 knock-down inhibited translation of ITAF-coding genes by $71 \%$ or $87 \%$, respectively (Fig. $7 \mathrm{C}$ and $7 \mathrm{D}$, Table S7). This inhibition concerned $57 \%$ or $89 \%$ of the remaining genes involved in angiogenesis and cardioprotection, for Neat 1 or Neat1_2 knock-down, respectively (Fig S6). In total, 92\% of the genes of the PCR array were less recruited into polysomes after Neat $1 \_2$ knock-down, versus only $56 \%$ after Neat 1 knockdown. These data strongly suggest that Neat1_2 might be a translational activator of families of genes involved in the response to hypoxic stress in cardiomyocytes.

\section{DISCUSSION}

The present data demonstrate a link between the paraspeckle and the control of IRES-dependent translation during hypoxia in mouse cardiomyocytes. We have identified a paraspeckle-related IRESome involving at least five ITAFs. Among them, three major paraspeckle components p5 $4^{\text {nrb }}$, PSPC1 and Neat1, as well as two proteins present in the p54 ${ }^{\text {nrb }}$ nuclear interactome, nucleolin and Rps2. PSPC1, Rps2 and Neat1 are novel ITAFs. Neat-1 appears as the key of this paraspeckle-related activation of translation in response to hypoxia : this lncRNA is an activator of all cellular IRESs tested, but not of the viral EMCV IRES. More broadly, Neat1_2 isoform activates the translation of most IRES-containing mRNAs and of several families of mRNAs involved in the response to hypoxia.

It may be noted that the inhibition of IRES activities resulting from ITAF depletion are quite moderate for the different proteins (20-40\%) while stronger for the lncRNA Neat 1 (40-70\%). This cannot be explained only by differences in knock-down efficiency. Our hypothesis is that several proteins are present in the IRESome complex and that there may be a certain redundancy between them. Thus the depletion of a single ITAF would not be sufficient to completely abolish the IRES activity. Also, to understand why paraspeckle ITAFs such as p54 ${ }^{\text {nrb }}$ and PSPC1 do not inhibit all the IRESs, we propose that the paraspeckle IRESome protein composition varies, depending on the IRES and on the hypoxic or normoxic condition. The only constant component of the IRESome formed in paraspeckle would be Neat1, the central player of the process. According to the data, the main actor of this mechanism is Neat 1_2: the peaks of Neat1_2 expression and its presence in paraspeckles fully correlate with the peak of IRES activation. Furthermore Neat 12 knock-down has a wider effect on translation control than Neat1 knock-down that targets the two Neat1 isoforms (Fig. 1 and Fig. 7).

We searched for an ITAF able to regulate a set of IRESs during hypoxia and we have found the lncRNA Neat 1 as a wide activator of IRES-dependent translation. However, our data show that Neat 1 also regulates IRES activities both in normoxia and in hypoxia. One explanation may be that Neat 1 is already expressed in normoxia in HL-1 cells, which are transformed cells despite their cardiomyocyte beating phenotype (Claycomb et al., 1998). Although Neat1 expression and paraspeckle number increase in response to hypoxia, a significant percentage of cells already contain paraspeckles in normoxia, which may explain why IRESs are already active in normoxia. It has been reported that Neat1_2 is not expressed in all tissues in vivo, whereas it is 
bioRxiv preprint doi: https://doi.org/10.1101/2021.02.10.430272; this version posted February 10, 2021. The copyright holder for this preprint (which was not certified by peer review) is the author/funder, who has granted bioRxiv a license to display the preprint in perpetuity. It is made available under aCC-BY-NC-ND 4.0 International license.

\section{Godet, David, Roussel et al, February 2021}

found in all transformed or immortalized cell lines (data not shown) (Nakagawa et al., 2011). In concordance with this observation, previous reports show that cellular IRESs are active in all cultured cell lines while inactive or tissue-specific in mice (Créancier et al., 2000, 2001).

A

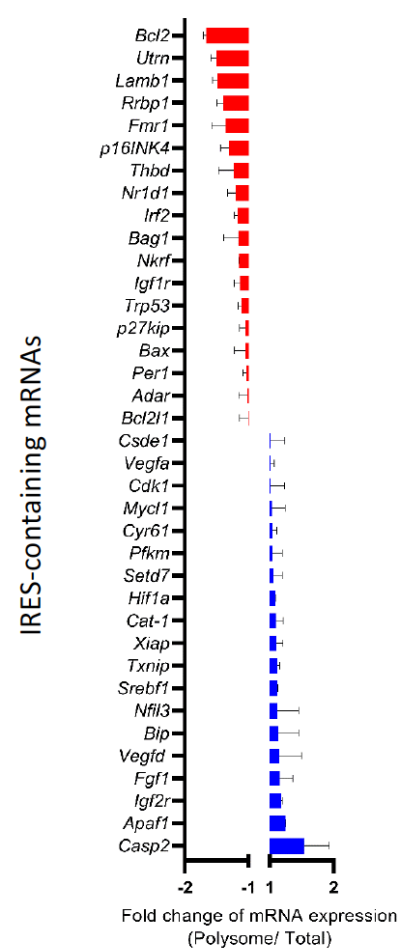

C

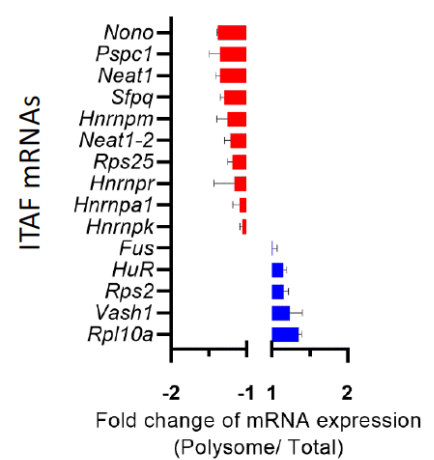

B

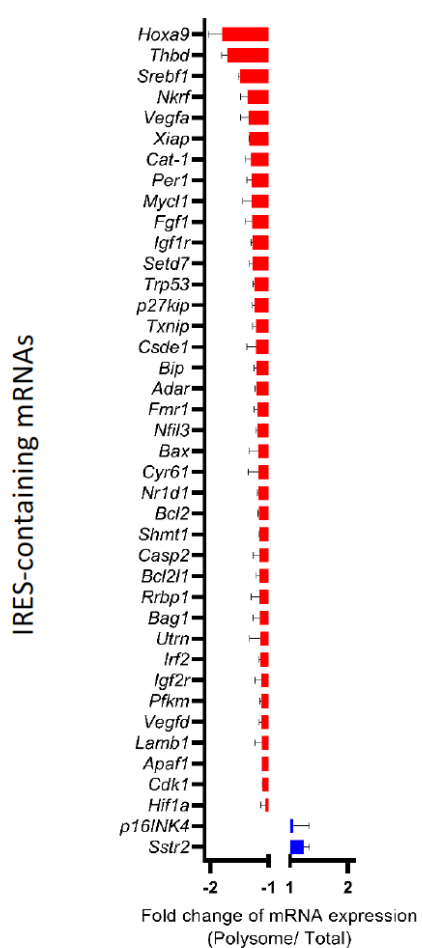

D Gapmer Neat1-2

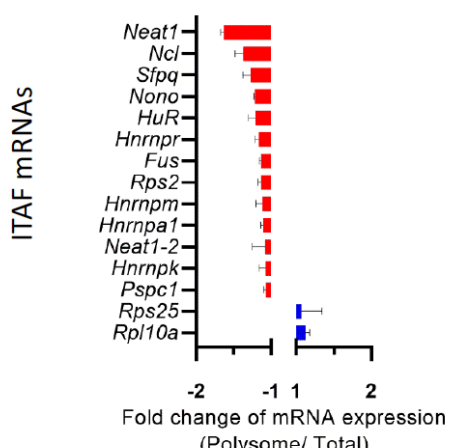

Figure 7. Neat1-2 knock-down down-regulates translation of most IRES-containing RNAs as well as mRNAs coding ITAFs.

HL-1 cardiomyocytes were transfected with gapmer Neat1, Neat1-2, or control. Polysomes were purified on sucrose gradient as described in Star Methods. The polysome profile is presented in Fig. S5. RNAs were purified from cytoplasmic extracts and from pooled polysomal fractions and analyzed on a Fluidigm deltagene PCR array from two biologicals replicates (cell culture dishes and cDNAs), each of them measured in three technical replicates (PCR reactions) (Table S7). IREScontaining mRNAs (A-B) and ITAF mRNA levels in polysomes (C-D) (polysomal RNA/ total RNA) were analyzed.

Relative quantification (RQ) of mRNA level was calculated using the $2-\Delta \Delta C T$ method with normalization to GAPDH mRNA and to HL-1 tranfected by gapmer control, and is shown as fold change of repression (red) or induction (blue).

Our data contrast with the study of Shen et al who showed that Neat 1 depletion allows to redistribute $\mathrm{p} 54^{\text {nrb }}$ and SFPQ/PSF onto the c-myc mRNA, in correlation with an increase in cMyc protein (Shen et al., 2017). Several reasons may explain this lack of concordance. Firstly, we used different cell lines, HL-1 cardiomyocytes for us, HeLa and MCF7 tumor cells for them. The regulation of IRES-dependent translation varies depending on cell lines. Secondly, they worked with human cell lines while HL-1 cells are of mouse origin. In human, c-myc expression is different from mouse as the c-myc gene contains an additional upstream promoter, $\mathrm{P} 0$, which generates a longer transcript with a second IRES (Nanbru et al., 2001). Thirdly, they have not directly analyzed the c-myc IRES activity but only the binding of p54 ${ }^{\text {nrb }}$ and SFPQ to the cmyc endogenous mRNA. Moreover an increase of c-myc protein expression does not necessarily correspond to an increase in IRES activity as the c-myc mRNA is also translated by 
bioRxiv preprint doi: https://doi.org/10.1101/2021.02.10.430272; this version posted February 10, 2021. The copyright holder for this preprint (which was not certified by peer review) is the author/funder, who has granted bioRxiv a license to display the preprint in perpetuity. It is made available under aCC-BY-NC-ND 4.0 International license.

Godet, David, Roussel et al, February 2021

the cap-dependent mechanism (Nanbru et al., 1997). Taken together, the two studies are different rather than discordant.

A surprising result has been the finding of a ribosomal protein, Rps 2 , in the nuclear $\mathrm{p} 54^{\mathrm{nrb}}$ interactome. This suggests an extra-ribosomal role of this protein. Its interaction with $\mathrm{p} 54^{\text {nrb }}$ favors the hypothesis that Rps 2 would impact the IRES activity as an IRESome component in the paraspeckle. The presence of nucleolin in the complex also suggests a link of paraspeckle with nucleolus and ribosome biogenesis. Supporting this, PSPC1 was first identified in the nucleolus proteome (Fox et al., 2002). The nuclear binding of specific ribosomal proteins to IRESs might be a mechanism to form specialized ribosomes.

Neatl is not the first lncRNA to exhibit an ITAF function. The lncRNA TP53-regulated modulator of p27 (TRMP) has been recently described as an ITAF of the p27 kip IRES (Yang et al., 2018). TRMP inhibits the $\mathrm{p} 27^{\mathrm{kip}}$ IRES activity by competing with the IRES for pyrimidine tract binding protein (PTB) binding and prevents IRES activation mediated by PTB. We have not yet deciphered the mechanism of action of Neat1. We propose that the paraspeckle would be a recruitment platform for IRES-containing mRNAs. Neat 1 , by interacting with $\mathrm{p} 54^{\text {nrb }}$ and other paraspeckle proteins/ITAFs would thus allow IRESome formation in the paraspeckle. Is the role of Neat 1 exclusively nuclear in the paraspeckle or is it exported to the cytoplasm with the IRESome complex? Two observations support the second hypothesis: on the one hand the triple helix in the 3'UTR of Neat1_2 has been reported for its role on translation activation (Wilusz et al., 2012). On the other hand, we have previously shown that Neat1 is present in HL1 cell polysomes and that this association with polysomes is increased in early hypoxia, suggesting a direct role in translation (Hantelys et al., 2019).

The model of IRESome formation mediated by Neat 1 in the paraspeckle, and the absence any impact of Neat1 on the picornaviral EMCV IRES activity, are both consistent with previous reports suggesting that the site of mRNA synthesis is crucial for IRES structure and function (Semler \& Waterman, 2008). For picornaviruses whose mRNAs are synthesized in the cytoplasm, IRES elements would be able to form an IRESome RNP in the cytoplasm. In contrast, cellular mRNAs (as well as DNA viruses and retroviruses mRNAs) transcribed in the nucleus need a nuclear event (Ainaoui et al., 2015; Stoneley et al., 2000). The present data provide a mechanism for this nuclear history and reveal a new function of the paraspeckle, a nuclear body, in IRESome formation.

A role of Neat1 in ischemic heart has been recently reported showing that Neat 1 downregulation would protect cardiomyocytes from apoptosis by regulating the processing of pri-miR-22 (Gidlöf et al., 2020). Surprisingly, these authors show that hypoxia downregulates Neat1 expression in cardiomyocytes. This contradicts our data showing that Neat 1 is induced by hypoxia. Our data are however in agreement with the rest of the literature showing that Neat 1 is induced by hypoxia in tumors, it transcription being activated by HIF-2 (Choudhry et al., 2015). Another study also shows that Neat overexpression protects cardiomyocytes against apoptosis, by sponging miR125a-5p, resulting in upregulation of the apoptosis repressor gene B-cell lymphoma-2-like 12 (BCL2L12)(Yan et al., 2019). These contradictory reports highlight the complex impact of Neat1 on miRNA-mediated gene regulation.

In the present study, we have uncovered a novel role of Neat 1 in the control of gene expression, by revealing that the longer isoform Neat 1-2 impacts the translational control of several families of genes involved in stress response, angiogenesis and cardioprotection, while it does not affect global translation. These effect is broad, as $92 \%$ of the genes present in the PCR array are less translated after Neat1-2 knock-down. The increased protein synthesis from mRNAs coding ITAFs favors a wide role of Neat1-2 and of the paraspeckle in the activation of IRES-dependent translation. Many of the genes involved in angiogenesis or cardioprotection tested here have not been described for containing an IRES in their mRNAs. We can make the hypothesis that these mRNA families either contain IRESs that have not been identified yet, or are translated by another cap-independent mechanism such as m6A-induced ribosome engagement sites (MIRES)(Prats et al., 2020). 
bioRxiv preprint doi: https://doi.org/10.1101/2021.02 10.430272; this version posted February 10, 2021. The copyright holder for this preprint (which was not certified by peer review) is the author/funder, who has granted bioRxiv a license to display the preprint in perpetuity. It is made available under aCC-BY-NC-ND 4.0 International license.

\section{Godet, David, Roussel et al, February 2021}

Neat1, as a stress-induced lncRNA, plays a role in many pathologies including cancer and ischemic diseases, thus its central role in the translational control of expression of genes involved in tissue revascularization and cell survival makes him a potential therapeutic target of great interest.

\section{STAR*METHODS}

Detailed methods are provided in the online version of this paper and include the following:

- KEY RESOURCES TABLE

- LEAD CONTACT AND MATERIALS AVAILABILITY

- EXPERIMENTAL MODEL AND SUBJECT DETAILS

- Cell lines

- Microbe strains

- METHOD DETAILS

- Cell transfection

- Cell transduction

- Lentivector construction

- Lentivector production

- Reporter activity assay

- FISH

- Western blot

- Capillary Western

- RNA purification and cDNA synthesis

○ qPCR

○ ddPCR

- Cell fractionation

- Immunoprecipitation

- In-gel digestion and mass spectrometry analysis

- MS-based protein identification

- Polysomal RNA preparation

- qPCR fluidigm array

- QUANTIFICATION AND STATISTICAL ANALYSIS

- qPCR and ddPCR analysis

- Label-free quantitative proteomics analysis

○ Dual luciferase system

- FISH

- Capillary Western

- Statistical analysis

\section{DATA AND CODE AVAILABILITY}

The MS proteomics data have been deposited to the ProteomeXchange Consortium via the PRIDE partner repository with the dataset identifier PXD0XXXXX.

The data/codes supporting the current study will be deposited in a public repository and are available from the corresponding author on request.

\section{SUPPLEMENTAL INFORMATION}

Supplemental information can be found online at https://doi.org 
bioRxiv preprint doi: https://doi.org/10.1101/2021.02.10.430272; this version posted February 10, 2021. The copyright holder for this preprint (which was not certified by peer review) is the author/funder, who has granted bioRxiv a license to display the preprint in perpetuity. It is made available under aCC-BY-NC-ND 4.0 International license.

Godet, David, Roussel et al, February 2021

\section{ACKNOWLEDGMENTS}

Our thanks go to J.J. Maoret and F. Martins from the Inserm UMR1297 GeT-TQ plateau of the GeT plateform Genotoul (Toulouse), and A. Lucas from the We-Met Functional Biochemistry Facility (Toulouse).

This work was supported by Région Occitanie (Midi-Pyrénées), Association pour la Recherche sur le Cancer (ARC), Fondation Toulouse Cancer Santé and Agence Nationale de la Recherche ANR-18-CE11-0020-RIBOCARD, European funds (Fonds Européens de Développement Régional, FEDER), Toulouse Métropole, and by the French Ministry of Research with the Investissement d'Avenir Infrastructures Nationales en Biologie et Santé program (ProFI, Proteomics French Infrastructure project, ANR-10-INBS-08). A.C.G, F.H. and E.R had fellowships from the Ligue Nationale Contre le Cancer (LNCC).

\section{AUTHOR CONTRIBUTIONS}

A.C.G., A.C.P., E.R. and F.D. conceived, and A.C.P. supervised the project. A.C.G., A.C.P., A.K.H., B.G.S., C.F., E.B., E.L., E.R., F.D., F.T., I.A. and P.V. designed the experiments. A.C.G., C.F., E.R., F.D., F.H., F.P. and J.A. performed the experiments. A.C.G., A.C.P., A.K.H., B.G.S. C.F., E.B., E.L., E.R., F.D., F.M., F.T., I.A., P.V. analysed the results. A.C.G., A.C.P., E.R. and F.D. wrote the manuscript. A.C.G., A.C.P., A.K.H., B.G.S., C.F. E.L, E.R., F.D., F.H., F.M., F.T. and O.B.S. corrected the manuscript.

\section{DECLARATION OF INTEREST}

The authors have no conflict of interest.

\section{REFERENCES}

Ainaoui, N., Hantelys, F., Renaud-Gabardos, E., Bunel, M., Lopez, F., Pujol, F., Planes, R., Bahraoui, E., Pichereaux, C., Burlet-Schiltz, O., et al. (2015). Promoter-Dependent Translation Controlled by p54nrb and hnRNPM during Myoblast Differentiation. PLoS One 10, e0136466.

Chen, J., Guo, K., and Kastan, M.B. (2012). Interactions of nucleolin and ribosomal protein L26 (RPL26) in translational control of human p53 mRNA. J. Biol. Chem. 287, 1646716476.

Choudhry, H., Albukhari, A., Morotti, M., Haider, S., Moralli, D., Smythies, J., Schödel, J., Green, C.M., Camps, C., Buffa, F., et al. (2015). Tumor hypoxia induces nuclear paraspeckle formation through HIF-2 $\alpha$ dependent transcriptional activation of NEAT1 leading to cancer cell survival. Oncogene 34, 4482-4490.

Claycomb, W.C., Lanson, N.A., Stallworth, B.S., Egeland, D.B., Delcarpio, J.B., Bahinski, A., and Izzo, N.J. (1998). HL-1 cells: a cardiac muscle cell line that contracts and retains phenotypic characteristics of the adult cardiomyocyte. Proc. Natl. Acad. Sci. USA 95, 29792984.

Clemson, C.M., Hutchinson, J.N., Sara, S.A., Ensminger, A.W., Fox, A.H., Chess, A., and Lawrence, J.B. (2009). An architectural role for a nuclear noncoding RNA: NEAT1 RNA is essential for the structure of paraspeckles. Mol. Cell 33, 717-726.

Cobbold, L.C., Spriggs, K.A., Haines, S.J., Dobbyn, H.C., Hayes, C., de Moor, C.H., Lilley, K.S., Bushell, M., and Willis, A.E. (2008). Identification of internal ribosome entry segment (IRES)-trans-acting factors for the Myc family of IRESs. Mol. Cell. Biol. 28, 40-49. Créancier, L., Morello, D., Mercier, P., and Prats, A.C. (2000). Fibroblast growth factor 2 internal ribosome entry site (IRES) activity ex vivo and in transgenic mice reveals a stringent tissue-specific regulation. J. Cell Biol. 150, 275-281. 
bioRxiv preprint doi: https://doi.org/10.1101/2021.02.10.430272; this version posted February 10, 2021. The copyright holder for this preprint (which was not certified by peer review) is the author/funder, who has granted bioRxiv a license to display the preprint in perpetuity. It is made available under aCC-BY-NC-ND 4.0 International license.

Godet, David, Roussel et al, February 2021

Créancier, L., Mercier, P., Prats, A.C., and Morello, D. (2001). c-myc Internal ribosome entry site activity is developmentally controlled and subjected to a strong translational repression in adult transgenic mice. Mol. Cell. Biol. 21, 1833-1840.

Fox, A.H., Lam, Y.W., Leung, A.K.L., Lyon, C.E., Andersen, J., Mann, M., and Lamond, A.I. (2002). Paraspeckles: a novel nuclear domain. Curr. Biol. 12, 13-25.

Fox, A.H., Bond, C.S., and Lamond, A.I. (2005). P54nrb forms a heterodimer with PSP1 that localizes to paraspeckles in an RNA-dependent manner. Mol. Biol. Cell 16, 5304-5315.

Gidlöf, O., Bader, K., Celik, S., Grossi, M., Nakagawa, S., Hirose, T., Metzler, B., Olde, B., \& Erlinge, D. (2020). Inhibition of the long non-coding RNA NEAT1 protects cardiomyocytes from hypoxia in vitro via decreased pri-miRNA processing. Cell death $\&$ disease, 11(8), 677. https://doi.org/10.1038/s41419-020-02854-7.

Godet, A.-C., David, F., Hantelys, F., Tatin, F., Lacazette, E., Garmy-Susini, B., and Prats, A.-C. (2019). IRES Trans-Acting Factors, Key Actors of the Stress Response. Int. J. Mol. Sci. 20.

Hantelys, F., Godet, A. C., David, F., Tatin, F., Renaud-Gabardos, E., Pujol, F., Diallo, L. H., Ader, I., Ligat, L., Henras, A. K., et al. (2019). Vasohibin1, a new mouse cardiomyocyte IRES trans-acting factor that regulates translation in early hypoxia. eLife, 8, e50094.

https://doi-org.proxy.insermbiblio.inist.fr/10.7554/eLife.50094

Hertz, M.I., Landry, D.M., Willis, A.E., Luo, G., and Thompson, S.R. (2013). Ribosomal protein S25 dependency reveals a common mechanism for diverse internal ribosome entry sites and ribosome shunting. Mol. Cell. Biol. 33, 1016-1026.

Hirose, T., Virnicchi, G., Tanigawa, A., Naganuma, T., Li, R., Kimura, H., Yokoi, T., Nakagawa, S., Bénard, M., Fox, A.H., et al. (2014). NEAT1 long noncoding RNA regulates transcription via protein sequestration within subnuclear bodies. Mol. Biol. Cell 25, 169-183. Holcik, M., and Sonenberg, N. (2005). Translational control in stress and apoptosis. Nat. Rev. Mol. Cell Biol. 6, 318-327.

Hu, C.-J., Wang, L.-Y., Chodosh, L.A., Keith, B., and Simon, M.C. (2003). Differential roles of hypoxia-inducible factor 1alpha (HIF-1alpha) and HIF-2alpha in hypoxic gene regulation. Mol. Cell. Biol. 23, 9361-9374.

Imamura, K., Imamachi, N., Akizuki, G., Kumakura, M., Kawaguchi, A., Nagata, K., Kato, A., Kawaguchi, Y., Sato, H., Yoneda, M., et al. (2014). Long noncoding RNA NEAT1dependent SFPQ relocation from promoter region to paraspeckle mediates IL8 expression upon immune stimuli. Mol. Cell 53, 393-406.

Kenneweg, F., Bang, C., Xiao, K., Boulanger, C.M., Loyer, X., Mazlan, S., Schroen, B., Hermans-Beijnsberger, S., Foinquinos, A., Hirt, M.N., et al. (2019). Long Noncoding RNAEnriched Vesicles Secreted by Hypoxic Cardiomyocytes Drive Cardiac Fibrosis. Mol. Ther. Nucleic Acids 18, 363-374.

Koh, M.Y., Lemos, R., Liu, X., and Powis, G. (2011). The hypoxia-associated factor switches cells from HIF-1 $\alpha$ - to HIF- $2 \alpha$-dependent signaling promoting stem cell characteristics, aggressive tumor growth and invasion. Cancer Res. 71, 4015-4027.

Lampe, S., Kunze, M., Scholz, A., Brauß, T.F., Winslow, S., Simm, S., Keller, M., Heidler, J., Wittig, I., Brüne, B., et al. (2018). Identification of the TXNIP IRES and characterization of the impact of regulatory IRES trans-acting factors. Biochim. Biophys. Acta Gene Regul.

Mech. 1861, 147-157.

Lee, M., Sadowska, A., Bekere, I., Ho, D., Gully, B.S., Lu, Y., Iyer, K.S., Trewhella, J., Fox, A.H., and Bond, C.S. (2015). The structure of human SFPQ reveals a coiled-coil mediated polymer essential for functional aggregation in gene regulation. Nucleic Acids Res. 43, 38263840 .

Morfoisse, F., Kuchnio, A., Frainay, C., Gomez-Brouchet, A., Delisle, M.-B., Marzi, S., Helfer, A.-C., Hantelys, F., Pujol, F., Guillermet-Guibert, J., et al. (2014). Hypoxia induces VEGF-C expression in metastatic tumor cells via a HIF-1 $\alpha$-independent translation-mediated mechanism. Cell Rep. 6, 155-167. 
bioRxiv preprint doi: https://doi.org/10.1101/2021.02.10.430272; this version posted February 10, 2021. The copyright holder for this preprint (which was not certified by peer review) is the author/funder, who has granted bioRxiv a license to display the preprint in perpetuity. It is made available under aCC-BY-NC-ND 4.0 International license.

Godet, David, Roussel et al, February 2021

Morfoisse, F., Tatin, F., Hantelys, F., Adoue, A., Helfer, A.-C., Cassant-Sourdy, S., Pujol, F., Gomez-Brouchet, A., Ligat, L., Lopez, F., et al. (2016). Nucleolin Promotes Heat ShockAssociated Translation of VEGF-D to Promote Tumor Lymphangiogenesis. Cancer Res. 76, 4394-4405.

Nakagawa, S., Naganuma, T., Shioi, G., and Hirose, T. (2011). Paraspeckles are subpopulation-specific nuclear bodies that are not essential in mice. J. Cell Biol. 193, 31-39. Nanbru, C., Lafon, I., Audigier, S., Gensac, M.C., Vagner, S., Huez, G., and Prats, A.C. (1997). Alternative translation of the proto-oncogene c-myc by an internal ribosome entry site. J. Biol. Chem. 272, 32061-32066.

Nanbru, C., Prats, A.C., Droogmans, L., Defrance, P., Huez, G., and Kruys, V. (2001). Translation of the human c-myc P0 tricistronic mRNA involves two independent internal ribosome entry sites. Oncogene 20, 4270-4280.

Passon, D.M., Lee, M., Rackham, O., Stanley, W.A., Sadowska, A., Filipovska, A., Fox, A.H., and Bond, C.S. (2012). Structure of the heterodimer of human NONO and paraspeckle protein component 1 and analysis of its role in subnuclear body formation. Proc. Natl. Acad. Sci. USA 109, 4846-4850.

Peddigari, S., Li, P.W.-L., Rabe, J.L., and Martin, S.L. (2013). hnRNPL and nucleolin bind LINE-1 RNA and function as host factors to modulate retrotransposition. Nucleic Acids Res. 41, 575-585.

Pouysségur, J., Dayan, F., and Mazure, N.M. (2006). Hypoxia signalling in cancer and approaches to enforce tumour regression. Nature 441, 437-443.

Prasanth, K.V., Prasanth, S.G., Xuan, Z., Hearn, S., Freier, S.M., Bennett, C.F., Zhang, M.Q., and Spector, D.L. (2005). Regulating gene expression through RNA nuclear retention. Cell 123, 249-263.

Prats, A. C., David, F., Diallo, L. H., Roussel, E., Tatin, F., Garmy-Susini, B., \& Lacazette, E. (2020). Circular RNA, the Key for Translation. International journal of molecular sciences, 21(22), 8591. https://doi-org.proxy.insermbiblio.inist.fr/10.3390/ijms21228591.

Semler, B. L., \& Waterman, M. L. (2008). IRES-mediated pathways to polysomes: nuclear versus cytoplasmic routes. Trends in microbiology, 16(1), 1-5. https://doi-

org.proxy.insermbiblio.inist.fr/10.1016/j.tim.2007.11.001.

Sharathchandra, A., Lal, R., Khan, D., and Das, S. (2012). Annexin A2 and PSF proteins interact with p53 IRES and regulate translation of p53 mRNA. RNA Biol. 9, 1429-1439. Shen, W., Liang, X.-H., Sun, H., De Hoyos, C.L., and Crooke, S.T. (2017). Depletion of NEAT1 lncRNA attenuates nucleolar stress by releasing sequestered P54nrb and PSF to facilitate c-Myc translation. PLoS One 12, e0173494.

Shi, Y., Yang, Y., Hoang, B., Bardeleben, C., Holmes, B., Gera, J., and Lichtenstein, A. (2016). Therapeutic potential of targeting IRES-dependent c-myc translation in multiple myeloma cells during ER stress. Oncogene 35, 1015-1024.

Shi, Z., Fujii, K., Kovary, K.M., Genuth, N.R., Röst, H.L., Teruel, M.N., and Barna, M. (2017). Heterogeneous Ribosomes Preferentially Translate Distinct Subpools of mRNAs Genome-wide. Mol. Cell 67, 71-83.e7.

Stoneley, M., Subkhankulova, T., Le Quesne, J. P., Coldwell, M. J., Jopling, C. L., Belsham, G. J., \& Willis, A. E. (2000). Analysis of the c-myc IRES; a potential role for cell-type specific trans-acting factors and the nuclear compartment. Nucleic acids research, 28(3), 687694. https://doi-org.proxy.insermbiblio.inist.fr/10.1093/nar/28.3.687

Sunwoo, H., Dinger, M.E., Wilusz, J.E., Amaral, P.P., Mattick, J.S., and Spector, D.L. (2009). MEN epsilon/beta nuclear-retained non-coding RNAs are up-regulated upon muscle differentiation and are essential components of paraspeckles. Genome Res. 19, 347-359. Takagi, M., Absalon, M.J., McLure, K.G., and Kastan, M.B. (2005). Regulation of p53 translation and induction after DNA damage by ribosomal protein L26 and nucleolin. Cell 123, 49-63. 
bioRxiv preprint doi: https://doi org/10.1101/2021.02.10.430272; this version posted February 10, 2021. The copyright holder for this preprint (which was not certified by peer review) is the author/funder, who has granted bioRxiv a license to display the preprint in perpetuity. It is made available under aCC-BY-NC-ND 4.0 International license.

\section{Godet, David, Roussel et al, February 2021}

Tatin, F., Renaud-Gabardos, E., Godet, A. C., Hantelys, F., Pujol, F., Morfoisse, F., Calise, D., Viars, F., Valet, P., Masri, B., et al. (2017). Apelin modulates pathological remodeling of lymphatic endothelium after myocardial infarction. JCI insight, 2(12), e93887. https://doiorg.proxy.insermbiblio.inist.fr/10.1172/jci.insight.93887

Wilusz, J.E., JnBaptiste, C.K., Lu, L.Y., Kuhn, C.-D., Joshua-Tor, L., and Sharp, P.A. (2012). A triple helix stabilizes the 3' ends of long noncoding RNAs that lack poly(A) tails. Genes Dev. 26, 2392-2407.

Yan, H., Liang, H., Liu, L., Chen, D., \& Zhang, Q. (2019). Long noncoding RNA NEAT1 sponges miR-125a-5p to suppress cardiomyocyte apoptosis via BCL2L12. Molecular medicine reports, 19(5), 4468-4474. https://doi.org/10.3892/mmr.2019.10095

Yang, C., Li, Z., Li, Y., Xu, R., Wang, Y., Tian, Y., and Chen, W. (2017). Long non-coding RNA NEAT1 overexpression is associated with poor prognosis in cancer patients: a systematic review and meta-analysis. Oncotarget 8, 2672-2680.

Yang, Y., Wang, C., Zhao, K., Zhang, G., Wang, D., and Mei, Y. (2018). TRMP, a p53inducible long noncoding RNA, regulates G1/S cell cycle progression by modulating IRESdependent p27 translation. Cell Death Dis. 9, 886.

Ylä-Herttuala, S., \& Baker, A. H. (2017). Cardiovascular Gene Therapy: Past, Present, and Future. Molecular therapy : the journal of the American Society of Gene Therapy, 25(5), 1095-1106. https://doi-org.proxy.insermbiblio.inist.fr/10.1016/j.ymthe.2017.03.027 